Elsevier required licence: (C) <2017>. This manuscript version is made available under the CC-BY-NC-ND 4.0 license http://creativecommons.org/licenses/bync-nd/4.0/ 
Multinational headquarter control of wholly owned foreign subsidiaries

\author{
Zoltan Matolcsy ${ }^{\mathrm{a}}$ \\ James Wakefield ${ }^{\mathrm{a} *}$ \\ ${ }^{a}$ University of Technology Sydney, Australia
}

*Corresponding author, James Wakefield

UTS Business School, Accounting, University of Technology Sydney

PO Box 123 Broadway, NSW 2007 Australia

Tel: +61 29514 3583; Email: James.Wakefield@uts.edu.au 


\title{
Multinational headquarter control of wholly owned foreign subsidiaries
}

\begin{abstract}
This paper examines how contingent factors relevant to the viability of wholly owned foreign subsidiary operations affect the management control system exercised by multinational corporation headquarters. We focus on two sets of contingent factors: first, strategic factors relating to corporate and competitive strategy; and second, integration factors relating to integration internal and external to a multinational corporation. We apply a control archetype approach to more comprehensively consider control exercised, relative to extant literature. Our evidence is based on data from a cross-sectional survey completed by 159 multinational corporation headquarters. Our findings indicate activity sharing corporate strategies, low cost competitive strategies, and higher internal integration, affect greater degrees of control. Differentiation based competitive strategies and external integration appear to have less substantial and narrower implications on the degree of control exercised. These findings are robust to sensitivity testing and are consistent with our expectations that headquarters exercise a higher degree of control in contexts perceived as less problematic.
\end{abstract}

Key words: Control archetypes, foreign subsidiaries, integration, management control system, strategy 


\section{Introduction}

The objective of this study is to examine the implications of contingent factors, important for wholly owned foreign subsidiary (WOFS) viability, on the management control system (MCS) exercised by multinational corporation (MNC) headquarters. In particular, we focus on two sets of contingent factors important for WOFS viability: first, the strategic factors relating to the scope of business involvement (corporate strategy) and the means of achieving a competitive advantage in the market (competitive strategy). Second, the degree of integration $^{1}$ both within an MNC (corporate embeddedness) and external to an MNC (external embeddedness). These factors, exhibiting significant heterogeneity across different firms, are important in relation to competitiveness and resource access (Forsgren, Pedersen, \& Foss, 1999; Goold, Campbell, \& Alexander, 1994; Kostova \& Zaheer, 1999; Tallman \& Fladmoe-Lindquist, 2002). We apply a control archetype ${ }^{2}$ approach to consider the degree of control exercised by headquarters, providing the basis of a more comprehensive understanding of control in this context.

Our motivation for this study is based on the continued importance of WOFS operations for MNCs emphasised in recent times. The importance of WOFS operations has been reaffirmed in many cases due to the challenging conditions MNCs face in home markets, for instance in parts of Europe and North America (Vachani, 2005). These operations provide a means of diversifying the geographic scope and market dependence of MNCs, while maintaining wholly owned control. Further, there has been a growth in emerging country based multinational corporations which now have a substantial presence in the global economy (Bonaglia, Goldstein, \& Mathews, 2007; Dunning, 2006; Luo \& Tang, 2007).

\footnotetext{
${ }^{1} \mathrm{We}$ focus on the concept of embeddedness given it is more defined from a conceptual and methodological perspective, compared with the concept of interdependence which is more broadly defined and examined in the literature.

${ }^{2}$ A control archetype is defined a set of control mechanisms exercised together (Speklé, 2001).
} 
The opportunities associated with WOFS operations also present challenges for MNC headquarters. Many operations are exposed to somewhat volatile and unpredictable environments at a distance from headquarters (Cuypers \& Martin, 2010; Shroff, Verdi, \& Yu, 2014; White, Hemphill, Joplin, \& Marsh, 2014). The importance of WOFS strategic and integration considerations for the viability of these operations is well articulated in management literature and appears no less important than ever (Forsgren, et al., 1999; Goold, et al., 1994; Kostova \& Zaheer, 1999; Tallman \& Fladmoe-Lindquist, 2002). Understanding the implications of these factors on headquarters' management control system is important in the interests of WOFS competitiveness and resource access.

Our evidence is based on a survey of Australian MNC headquarters controlling WOFS operations for which we received 159 usable responses. We find that activity sharing corporate strategies, low cost competitive strategies, and high corporate embeddedness, are associated with high degrees of control exercised (based on the control archetypes). This is consistent with the less problematic nature of controlling WOFS operations in the context of these factors, along with headquarters' desire to more tightly control operations at a distance where possible (Giacobbe, Matolcsy, \& Wakefield, 2016). Differentiation based competitive strategies and external embeddedness have less substantial and narrower effects on the degree of control exercised. These effects can be linked to the more problematic nature of controlling WOFS operations exhibiting these factors, based on the transaction cost economics (TCE) theoretical approach that we apply in this study.

Through applying a control archetype approach to considering the degree of control exercised, this study contributes to existing literature by addressing concerns associated with fragmentary consideration of control (Berry, Coad, Harris, Otley, \& Stringer, 2009). Literature concerning the implications of contingent factors we examine, particularly relating to integration, on more comprehensive conceptualisations of control is limited; this is 
surprising given the economic significance of WOFS operations. We build on the findings of prior literature concerning control of WOFS operations (Giacobbe, et al., 2016), develop a deeper understanding of contingent factor implications on control choices, and contribute to the substantial body of contingency research in literature (Ashton, et al., 2009). In addition, given the relevance of contingent factors to practice, our study alleviates research-practice gap translation issues (Tucker \& Lowe, 2014).

In this paper we first present the literature review and theory development, where the hypotheses are presented. Next we describe the research method, followed by the results and associated discussion. We then present sensitivity testing and additional modelling before we conclude and suggest opportunities for future research.

\section{Literature review and theory development}

A review of the literature indicates the study of WOFS operations and related control, in this distinct context, is limited. Many studies generally group a range of entities into the general category of foreign subsidiaries for the purpose of analysis, ranging from joint ventures to WOFS operations (Jaussaud \& Schaaper, 2006). This is problematic because there are notable differences concerning the organisational dynamics and control associated with partially and fully owned entities (Giacobbe \& Booth, 2009; Talay \& Cavusgil, 2008). Accordingly, the generalisability of findings to the WOFS specific entity type may be limited (Abernethy, Bouwens, \& Lent, 2004; Chenhall, 2003; Langfield-Smith, 1997). We specifically examine control of WOFS operations, addressing this problematic issue.

Many factors are relevant to the degree of control exercised by MNCs over WOFS operations, consistent with the domain of contingency theory (Chenhall, 2003). We identify several factors important for the viability of WOFS operations which we predict shape the control headquarters' exercise across the two categories of strategic factors and subsidiary 
integration. According to the suggestions of literature, these factors relate to subsidiary viability when controlled from a distance particularly when facing challenges presented by intensive market competitiveness and developmental processes associated with establishing and/or operating a subsidiary in a foreign market (Agbejule, 2005; Hoque, 2005; Muralidharan \& Hamilton, 1999). The acquisition and possession of knowledge and other resources these factors facilitate is central to the subsidiary viability (Forsgren, et al., 1999; Goold, et al., 1994; Kostova \& Zaheer, 1999; Tallman \& Fladmoe-Lindquist, 2002).

We apply a TCE theory approach to this study as it provides a parsimonious perspective to consider the implications of contingent factors on control exercised; this addresses concerns regarding diverse and fragmented approaches noted in literature (Christensen \& Kent, 2015; Spicer \& Ballew, 1983; Williamson, 1979, 2008). In particular, we theorise the links between our contingent factors and control exercised through considering TCE activity traits (uncertainty, asset specificity and ex-post information asymmetry). Different combinations of activity traits and related human traits (bounded rationality and opportunism), driven by contingent factors, are argued to be associated with distinct control problems, addressed through the control exercised (Kruis, 2008; Speklé, 2001). Central to the contingent factors we examine is the importance they have from the perspective of knowledge and other viability related resources. Such resources are at distance, from headquarters, and associated factor variation is expected to drive uncertainty, asset specificity and ex-post information asymmetry. The expected implications of each contingent factor on control exercised is explained in the hypotheses development, later in this section.

The control archetype approach we apply in this study, based on Speklé's (2001) TCE theory of management control, provides notable opportunities to develop a more comprehensive and holistic understanding of control, beyond the examination of single control mechanisms in much of literature (Shields, 2015). There are a range of alternative control frameworks in 
literature; however, the consideration of different sets of control mechanisms applied together is very limited (Malmi \& Brown, 2008; Merchant \& Van der Stede, 2012; Simons, 1994), particularly in the context of the factors we consider, notably strategy (Tucker, Thorne, \& Gurd, 2009; Tucker \& Parker, 2015). Speklé (2001) conceptualises a series of control archetypes which are argued to be exercised in association with variation in the activity traits (based on TCE theory). These control archetypes, described in the context of headquarters controlling WOFS operations, are as follows:

- Arm's length control: High relative autonomy provided to subsidiary management, with headquarter invention if performance is unsatisfactory. Market based benchmarks applied for the purpose of targets, monitoring, evaluation and rewards.

- Results oriented machine control: High relative autonomy provided to subsidiary management within a framework of internally developed performance targets, providing the basis of monitoring, evaluation and rewards.

- Action oriented machine control: Low relative autonomy provided to subsidiary management within a framework of clearly defined tasks, standardised behaviour and limited scope for discretionary behaviour. Close monitoring of norms and standards.

- Exploratory control: High relative autonomy provided to subsidiary management and performance targets established as information emerges, which form the basis of monitoring and subjective evaluation of subsidiary management. Rewards based on long-term performance.

- Boundary control: High relative autonomy within clearly specified behavioural boundaries, including decision-making authority, which headquarters monitors closely and takes action if there are breaches. 
From an empirical perspective, Giacobbe et al. (2016) is one of the few studies examining the validity of this control archetype approach and provides support that these archetypes are valid representations of different sets of control mechanisms exercised. They find that these distinct control archetypes are observed, however, they are used in combination rather than exclusively, as suggested by Speklé (2001). Further, Giacobbe et al. (2016) find that generally, more problematic control contexts, as measured by activity traits in TCE theory, are associated with control archetypes being exercised to a lower degree. In particular, higher levels of uncertainty, asset specificity and ex-post information asymmetry, from the headquarters' perspective, are associated with the five control archetypes being exercised to a lower degree, to varying extents. These findings provide the basis of our theoretical and hypotheses development that follows below, allowing us to consider the implications of the contingent factors we examine on control exercised. Specifically, we consider the implications of contingent factors on the overall degree of control exercised by headquarters, given headquarters appear to exercise control archetypes in combination together (Giacobbe, et al., 2016).

\subsection{Corporate strategy (headquarters level)}

In this study corporate strategy is defined as the investment approach of headquarters concerning the variation in business involvement. The scope of corporate strategy ranges from activity sharing (one line of business) to portfolio management (multiple and diversified businesses) (Goold, Campbell, \& Luchs, 1993; Porter, 1987). While synergies between organisational units (including subsidiaries) may be associated with corporate strategy, synergies are captured and analysed as a separate variable (corporate embeddedness) in this study.

Headquarters' engagement in related businesses under an activity sharing strategy increases its ability to process ex-ante information widely applicable to subsidiaries, minimising 
uncertainty faced by headquarters controlling a number of WOFS operations (Chandler, 1962; Goold \& Luchs, 2003; Nilsson, 2002). Bounded rationality becomes more problematic with the movement from activity sharing to portfolio management strategies, where headquarters are less familiar with operations and process relatively low amounts of information about unrelated businesses (Argyres, 1995; Nilsson, 2002). Accordingly, headquarters are likely to be less effective at defining comprehensive processes or expectations for portfolio management, compared with activity sharing corporate strategies.

The implications of corporate strategy on asset specificity are less clear. The relatively narrow scope of business involvement under an activity sharing strategy may lead to the development of corporation specific routines, management skills and practices. This may allow resources from the WOFS to be diverted to other areas of the MNC if necessary (Anand \& Singh, 1997; Williamson, 1975). However, whether or not this is practical in the context of the WOFS operations controlled at a distance from other divisions is questionable. Resources in WOFS operations controlled under a portfolio management strategy may be more tailored to the unique and specific nature of each operation. This may mean that it is problematic to redirect these resources.

Similar to ex-ante information, ex-post information asymmetry is expected to be lower under an activity sharing strategy compared with a portfolio management strategy, consistent with the similarity of business involvement in the corporation. The narrow scope of business area involvement under an activity sharing strategy enhances headquarters' ability to identify and assess key performance indicators concerning subsidiary performance (Park, 2002). In contrast, under a portfolio management strategy the diversity of different businesses minimises headquarters' ability to identify key performance indicators, particularly nonfinancial indicators, and identify desired performance outcomes (Park, 2002). 
According to TCE characteristics, headquarters appear to face a more problematic context when exercising control under a portfolio management approach to corporate strategy due to relatively higher uncertainty, possibly higher asset specificity, and higher ex-post information asymmetry concerning WOFS operations. A higher degree of control overall (based on the five control archetypes) is likely to be suboptimal due to headquarters' bounded rationality concerning control exercised, and subsidiary personnel opportunism through manipulating various performance metrics and information flows. In contrast, under an activity sharing strategy, greater ex-ante and ex-post information concerning WOFS operations and possibly lower levels of asset specificity means headquarters are in a better position to exercise a higher degree of control. Based on prior literature, we expect headquarters to exercise a lower degree of control (through the five control archetypes) in the context of a portfolio management, relative to activity sharing, corporate strategy given it is a less problematic context. Therefore, we propose:

H1: A portfolio management strategy, relative to activity sharing, is associated with a lower degree of control.

\subsection{Competitive strategy (WOFS level)}

Competitive strategy refers to the means by which a subsidiary competes and achieves a competitive advantage in the market it operates (Langfield-Smith, 1997). Controls exercised by headquarters should be consistent with the autonomy needed by subsidiary management to operationalise, monitor and modify competitive strategy to realise the benefits of competitive strategy (Kober, Ng, \& Paul, 2007; Simons, 1994). While there is generally substantial literature regarding the association between control and competitive strategy (Chenhall, 2003), examination in the context of WOFS operations, where headquarters is at a distance is limited. In addition, there is limited literature dealing more comprehensive considerations of 
control. Accordingly, we examine competitive strategy effects, particularly given the importance associated with subsidiary viability.

Low cost competitive strategies are characterised by the drive for production efficiencies and operational continuity as organisations seek to maintain competitiveness in markets with high product homogeneity (Chenhall \& Langfield-Smith, 1998; Miles \& Snow, 1978). Consistent with the importance of efficiency, there is greater continuity of operations suggesting headquarters have greater ex-ante information regarding WOFS operations, lowering uncertainty (Williamson, 1979; Williamson, 2005). Ex-post information asymmetry is also expected to be lower, again consistent with continuity of operations, suggesting headquarters establish and consistently monitor key performance indicators (Birkinshaw, Toulan, \& Arnold, 2001; Dunning, 1993; Kruis, 2008).

The specificity of assets in the context of low cost competitive strategies is generally expected to be lower (Williamson, 1975). This is consistent with the wider marketability of products produced for a range of customers where there is limited variation in preferences. Accordingly, the ability to redeploy assets to serve alternative customers is high.

The combination of the low uncertainty, ex-post information asymmetry and asset specificity, and accordingly a less problematic context, suggests headquarters are in a position to exercise a higher degree of control through the five control archetypes. This is consistent with the lower likelihood of both headquarters being exposed to bounded rationality concerning control exercised and the opportunistic motives of subsidiary personnel reducing the effectiveness of control exercised. Accordingly, we propose:

H2: Low cost competitive strategies are associated with a higher degree of control. 
Competitive strategies based on differentiation generally relate to taking advantage of new market opportunities through the development of new products and/or markets (Miles \& Snow, 1978). The continuity of subsidiary operations is therefore lower, relatively, and subsidiary personnel are required to be more dynamic to take advantage of emerging opportunities. Consistent with the dynamic nature of operations in this situation, headquarters are expected to have relatively limited ex-ante knowledge regarding WOFS processes and activities, causing higher uncertainty (Williamson, 1979; Williamson, 2005). Further, the greater variation in subsidiary operations to exploit new market opportunities suggests headquarters' ability to monitor the performance outcomes of subsidiary operations is limited and accordingly ex-post information asymmetry is high (Birkinshaw, et al., 2001; Dunning, 1993; Kruis, 2008).

Resources under differentiation competitive strategies are specifically tailored and evolve according to opportunities emerging in the market place. Accordingly, assets are specific to products produced and sold - possibly for a niche market. The ability to redeploy assets to serve alternative customers is expected to be relatively limited (Williamson, 1975).

Based on the indications of literature, the presence of a differentiation competitive strategy is expected to be associated with higher uncertainty, ex-post information asymmetry and asset specificity, and therefore a more problematic context to control. This presents challenges from the perspective of headquarters concerning bounded rationality when choosing control and the effectiveness of such control is questionable due to opportunistic WOFS personal motives. Therefore, we propose:

\section{H3: Differentiation competitive strategies are associated with a lower degree of control.}

According to the literature, low cost and differentiation competitive strategies are not mutually exclusive choices, but are blended together and jointly exercised (Adler, 2011; 
Murray, 1988). For this reason, separate hypotheses are needed concerning the effects of different competitive strategies on control exercised.

\subsection{Corporate embeddedness (WOFS level)}

Corporate embeddedness refers to subsidiary adaptation to entities within a MNC, associated with synergies between entities facilitating resource sharing (Andersson \& Forsgren, 1996). We consider the implications of both tangible and intangible resource flows associated with corporate embeddedness, more comprehensively than prior literature which considers tangible resource flows only (Baliga \& Jaeger, 1984; Gupta \& Govindarajan, 1984; Thompson, 1967). Intangible resource flows are an important aspect of corporate embeddedness, particularly for knowledge intensive firms (Ditillo, 2004). For the purpose of our study corporate embeddedness and corporate strategy are distinct concepts, referring to corporate integration and investment approaches respectively (Andersson \& Forsgren, 1996; Goold, et al., 1993; Porter, 1987).

The potential for cross business unit synergies to be realised, maintained and enhanced where corporate embeddedness is high means headquarters are incentivised to acquire information concerning subsidiary operations, reducing the level of uncertainty (Chandler, 1991). This contrasts with low subsidiary corporate embeddedness, where the incentive and ability of headquarters to acquire information is limited (Baliga \& Jaeger, 1984; Freeland, 1996; Gupta \& Govindarajan, 1991; Hill, Hitt, \& Hoskisson, 1992; Williamson, 1975). Accordingly, greater information concerning subsidiary operations where corporate embeddedness is high increases the ability of headquarters to specify processes and ex-ante expectations at the subsidiary level (Williamson, 1979; Williamson, 2005).

Again, similar to the possible effects of corporate strategy, the implications of corporate embeddedness on asset specificity are less clear. Following the definition of corporate 
embeddedness suggests assets are specifically adapted to resource flows between entities (Andersson \& Forsgren, 1996). Accordingly, this facilitates the movement of resources from one subsidiary to another, reducing asset specificity from a corporate perspective. However, the ability to divest subsidiary resources from the MNC may be limited given the corporate embeddedness between different entities. Such divestment may have wider reaching implications for the MNC as a whole and expose the corporation to significant risk of large opportunity losses (Collis \& Montgomery, 1997; Freeland, 1996; Williamson, 1975). The effects of corporate embeddedness on asset specificity appear therefore to depend on whether the resources can be reallocated internally or externally from the MNC.

The degree to which a subsidiary is adapted to other entities across the MNC determines how interrelated its performance is with these entities (Andersson \& Forsgren, 1996). High corporate embeddedness levels are likely to be associated with common benchmarks, allowing relative performance assessment, consistent with high adaptation between WOFS operations. This suggests corporate embeddedness decreases the ex-post information asymmetry headquarters face.

Based on TCE characteristics, headquarters appear to face a less problematic context where corporate embeddedness is high. Bounded rationality concerning headquarters' control choices and opportunistic subsidiary personal behaviour, through manipulation of metrics and information associated with control, is likely to be minimal under high corporate embeddedness. Consistent with these suggestions, we propose:

\section{H4: Corporate embeddedness is associated with a higher degree of control.}

\subsection{External embeddedness (WOFS level)}

External embeddedness refers to the adaptation of a subsidiary to entities within the business context in which it is located, including customers, suppliers, distributors, government 
organisations and professional trade associations (Håkansson \& Snehota, 1995). High external embeddedness generally enhances the ability of subsidiary management to acquire knowledge of the market (Hansen, 1999; Lane \& Lubatkin, 1998). Integration and adaptation is a constant process in order to maintain or enhance market competitiveness (Abdel-Kader \& Luther, 2008; Andersson, Bjorkman, \& Forsgren, 2005).

Given the constant evolution of WOFS operations which are highly externally embedded, it is expected that headquarters finds it challenging to acquire and process relevant information from a distance (Ghoshal, Korine, \& Szulanski, 1994; Hansen, 2002; Schulz, 2001). Accordingly, headquarters have limited ex-ante information relating to factors including government regulations, market trends and customer preferences (Birkinshaw, et al., 2001; Dunning, 1993). This suggests the external embeddedness is associated with higher uncertainty concerning subsidiary operations (Williamson, 1979; Williamson, 2005)..

A wider group of interested parties is expected to value WOFS external embeddedness, particularly if these parties have associations with subsidiary operations (for example, suppliers and customers). Accordingly, the opportunity for headquarters to divest highly externally embedded WOFS operations is expected to be greater, reducing asset specificity and opportunity costs.

The evolution of a highly externally embedded WOFS over time, as it adapts to the local context, suggests that performance assessment and evaluation need to be continually adapted. Headquarters' ability to use the most relevant measures to accurately capture performance in situations of high external embeddedness may be difficult, particularly given foreign market ambiguity (Tihanyi \& Thomas, 2005; Ungson, Braunstein, \& Hall, 1981). Accordingly, external embeddedness appears to drive higher ex-post information asymmetry from headquarters' perspective (Williamson, 1979; Williamson, 2005). 
Headquarters appear to find the context of high external embeddedness more problematic from a control perspective. While asset specificity may be lower, uncertainty and ex-post information asymmetry are higher. Accordingly, bounded rationality concerning headquarters' control exercised, and issues associated opportunistic motives of WOFS personnel, are more likely. We therefore propose:

\section{H5: External embeddedness is associated with a lower degree of control.}

\section{Research method}

We conducted a cross sectional survey questionnaire following Dillman (2000). The survey instrument is provided in Appendix A. The survey was sent to senior managers at MNC headquarters who were involved in the control of WOFS operations. We received 178 responses (a response rate of 28.8\%). Nine responses were removed from the sample due to incomplete survey completion and ten were removed as they related to dormant subsidiaries, zero employee subsidiaries, leaving 159 firm responses for the purpose of our analysis. Survey respondents indicated they had been working at their company for an average of 9.58 years and currently held senior positions, as described in Table 1 below.

\section{[INSERT TABLE 1 HERE]}

There was a large variation in respondent characteristics, with MNCs employing between 538,000 people, while their focal WOFS employed between 1-5,000 people. We include a size control variable in our regression models to take this variation into account. As shown in Table 2 below, respondent firms are involved in diverse industries (Panel A) and subsidiary locations (Panel B), generally reflective of multinational firm involvement.

\section{[INSERT TABLE 2 HERE]}


To address concerns regarding non-response bias, we compared the variable means of early and late responses. The means of the constructs for early and late respondents are not significantly different according to the $t$-statisitcs, with the exception of external embeddedness. However, given the difference in the early and late respondent means for external embeddedness is small ( 0.297 difference on the 5 point Likert scale), and all other differences are statistically insignificant, non-response bias is not a concern in this study. In addition, we also examined whether common method bias was a concern through Harman's single-factor test. Based on all 31 indicators applied to measure the construct variables in this study (detailed below), Harman's single factor test results in nine factors with eigenvalues greater than one, with the strongest factor explaining $20.9 \%$ of the total variance. This suggests common method bias is not a concern in this study (Podsakoff \& Organ, 1986).

\subsection{Variable measurement}

In order to measure the management control system (MCS) and contingent factors and (constructs), the relevant indicators ${ }^{3}$ are combined though simple additive aggregation (after relevant validity testing).

\subsubsection{Control measurement}

We measure control through two stages. First, we measure Speklé's (2001) individual control archetype conceptualisations by adapting indicators and associated survey questions from Kruis (2008) and applying them to the WOFS operations context. The control archetype indicators and associated survey questions are summarised in Table B.1 (Appendix B). The validity of these control archetypes are examined by Giacobbe et al. (2016) whose findings indicate these archetypes are representative of distinct control choices. However, they also find these control choices are not exercised independently as Speklé (2001) suggests;

\footnotetext{
${ }^{3}$ Indicator measurement scales are reversed where appropriate to ensure that higher construct value convey higher degrees of the relevant phenomenon.
} 
accordingly we measure the degree each independent control archetype is exercised. To determine the construct values for each control archetype, the relevant indicators, as shown in Table B.1, are factor analysed and aggregated.

In the second stage, we aggregate the five control archetype constructs to create a second order construct measuring the overall degree of control exercised by headquarters. This construct will initially be applied as the dependent variable in the regression models to test the hypotheses. This construct is regarded as a second order formative construct given the distinct nature of each control archetype aggregated. While headquarters are expected to use combinations of control archetypes to affect a certain degree of control, each archetype is unique and relates to distinct control mechanisms and therefore is not expected to be a reflective underlying construct.

\subsubsection{MNC corporate strategy}

The MNC corporate strategy is captured through indicators from Rumelt (1974) which relate to the specialisation and related ratio; this measures the revenues attributable to the core area of business and the extent of involvement in one product area respectively (survey question 11a-c). These ratios are measured according to perceptual Likert scales in this study, given ratio based data is difficult to reliably gather through a survey instrument.

\subsubsection{Competitive strategy}

Competitive strategy is a multifaceted variable and accordingly a series of different indicators are applied to measure it in this study (Dess \& Davis, 1984; Langfield-Smith, 1997). Specifically, we apply two sets of indicators to measure competitive strategy, the first set focuses on low cost competitive strategies and is based on the extent operating efficiency, competitive pricing, procurement of product inputs, reducing production costs, and minimisation of outside financing are important for competitiveness (survey question 12a-e). 
The second set of indicators focuses on differentiation competitive strategies and is based on the importance of new product development, brand identification, innovative marketing techniques, control of distribution channels, and advertising for competitiveness (survey question 12f-j).

\subsubsection{Corporate embeddedness}

Guidance from prior studies on how to measure corporate embeddedness is limited beyond the suggestions of Andersson and Forsgren (1996). Given embeddedness is defined by the degree of adaptation to other entities (Andersson, Forsgren, \& Holm, 2001, 2007), it is appropriate to capture the extent a foreign subsidiary adapts operations to other entities within an MNC to measure corporate embeddedness (survey question 13e).

\subsubsection{External embeddedness}

Since external embeddedness relates to subsidiary adaptation to stakeholders in the context it operates, Dimiratos, Liouka and Young (2009) argue it is important to consider customers, suppliers, distributors, government organisations and professional trade associations when measuring this variable. Based on Andersson, Forsgren and Holm (2002), external embeddedness is measured by the extent a subsidiary adapts the way it conducts business with stakeholders (survey question 13a-d).

\subsubsection{Variable measurement validity}

To confirm the validity of the constructs ${ }^{4}$ and associated indicators we first examine the rotated factors loadings. Indicators with factors loadings less than 0.5 (acceptable threshold) are removed from the factor analysis and construct measurement (Jarvis, Mackenzie, \& Podsakoff, 2003). The final factor loadings are reported in Table C.1 (Appendix C) with the

\footnotetext{
${ }^{4}$ Corporate embeddedness is measured on the basis of one indicator, consistent with existing literature. The validity testing conducted is appropriate for constructs measured with two or more indicators and therefore corporate embeddedness is not included in this validity testing section. Given the measurement validity of the other constructs in this study, we have no reason to believe the single indicator measurement is problematic.
} 
indicators remaining closely aligned with the unique and underlying characteristics of each construct, consistent with the reflective nature of construct indicators. Second, we examine the internal consistency of the construct indicators through Cronbach's alpha. All alphas are close to or higher than 0.70, as reported in Table C.2 (Appendix C), indicating acceptable composite reliability. ${ }^{5}$ Finally, we examine the discriminant validity of the constructs by comparing the square root of the average variance extracted to construct correlations (Fornell \& Larcker, 1981), reported in Table C.3 (Appendix C). The value of the square root of $A V E$ is higher than the correlations in all cases, indicating acceptable discriminant validity, with the exception of action-oriented machine and boundary control. This indicates it may be problematic to discriminate between action-oriented machine and boundary control, consistent with the direct nature of these control archetypes. However, all other control archetypes appear discriminately valid, consistent with the formative nature of the second order degree of control construct. The descriptive statistics of the variables explained in this section are provided below in Table 3. The descriptive statistics have sufficient variation for the purpose of the regression analysis.

\section{[INSERT TABLE 3 HERE]}

\subsection{Regression modelling}

Consistent with our measurement of control, we analyse the effects of contingent factors in two ways using ordinary least square (OLS) regression modelling. First, we analyse the effect of contingent factors on the overall degree of control exercised (second order construct), providing a direct test of our hypotheses. Second, we analyse the effect of contingent factors on each of the five control archetype variables, providing a more detailed analysis relating to

\footnotetext{
${ }^{5}$ For the purposes of consistency, we report the rotated factor loadings and internal consistency for the degree of control. As expected, given the formative nature of this second order construct, rotated factor loadings and internal consistency are lower.
} 
the contingent factor effects on more distinct mechanisms of control. The regression models are represented by the following (Model 1):

$$
\begin{aligned}
& \text { (1) CONTROL }{ }_{i}=\alpha_{0}+\alpha_{1} \text { CORP_STRATEGY } Y_{i}+\alpha_{2} L O W C O S T \_S T R A T E G Y_{i}+ \\
& \alpha_{3} \text { DIFF_STRATEGY } Y_{i}+\alpha_{4} C O R P \_E M B E D_{i}+\alpha_{5} E X T_{-} \text {EMBED } D_{i}+\alpha_{6} S I Z E_{i}+\varepsilon_{i}
\end{aligned}
$$

where:

CONTROL: Based on the explanation above (Section 3.1.1), the following control variables are applied in our regression models:

DEGREE_CONTROL: measures the degree of control exercised based on aggregating the five control archetypes, with high values indicating a high degree of control exercised.

CONTROL_ARCHETYPE: measures the degree each individual control archetype is exercised by headquarters, through continuous variables, with high values representing greater use of each control archetype. One OLS regression is run for each of the five control archetypes in order to examine the effects of the contingent factors on these control archetypes.

CORP_STRATEGY: measures the corporate strategy of the MNC. Low values indicate an activity sharing strategy, whereas high values indicate a portfolio management strategy.

LOWCOST_STRATEGY: measures the extent to which a subsidiary has a low cost competitive strategy. High values indicate the use of a low cost competitive strategy. DIFF_STRATEGY: measures the extent to which a subsidiary has a differentiation competitive strategy. High values indicate the use of a differentiation competitive strategy.

CORP_EMBED: measures the extent of corporate embeddedness. High values indicate high corporate embeddedness. 
$E X T \_E M B E D$ : measures the extent of external embeddedness. High values indicate high external embeddedness.

SIZE: size is included as a control variable, based on the number of people employed at a MNC, given it is regarded as an important control variable in the literature (Chenhall, 2003).

\section{Results and discussion}

The results of the OLS regressions are presented in Table 4 below.

\section{[INSERT TABLE 4 HERE]}

The F-statistic in all regression models is significant at the one percentage level (two-tailed), with the adjusted $\mathrm{R}$ square values ranging from $8.4 \%$ to $26.0 \%$. These $\mathrm{R}$ square values are more substantial in some cases than the variation explained by TCE activity traits in prior studies (Giacobbe, et al., 2016). The variance inflation factors (VIF) are lower than five in all cases, indicating multi-collinearity is not a concern (O'Brien, 2007).

\subsection{Corporate strategy}

The coefficient for corporate strategy is negative and significant in the degree of control model (coefficient: -0.216 , $p$-value: 0.003), supporting Hypothesis 1. Further, this result is consistent in each of the control archetype models, with the exception of arm's length control. These results indicate headquarters exercise a lower degree of control in the presence of a portfolio management corporate strategy and a higher degree of control in the presence of an activity sharing corporate strategy.

The lack of a statistically significant coefficient for corporate strategy in the arm's length regression model may be explained by the broader applicability of this control archetype regardless of corporate strategy (Sandino, 2007). Situations of activity sharing strategies may be associated with readily available market benchmarks from the perspective of headquarters. 
The use of portfolio management strategies may be associated with the need for external market benchmarks in the absence of suitable internal benchmarking. Accordingly, while we are not arguing that use of the arm's length control in all corporate strategy situations is appropriate, the importance headquarters place on this control archetype is similar.

\subsection{Competitive strategy}

\subsubsection{Low cost competitive strategy}

The coefficient for low cost competitive strategy is positive and statistically significant in the degree of control model (coefficient: 0.268, p-value: 0.000), supporting Hypothesis 2. Further, this result is consistent in each of the control archetype models with the exception of the results oriented machine control model. These results clearly indicate headquarters exercise a higher degree of control where WOFS competitive position is more closely associated with a low cost competitive strategy. This indicates low cost competitive strategy characteristics have a substantial effect on activity trait levels, consistent with the suggestions of the literature (Giacobbe, et al., 2016; Speklé, 2001). The fact that low cost competitive strategies have a substantial effect on control choices does not come as a surprise given the extensive literature on the topic (Chenhall, 2003). However, our finding, concerning the overall degree of control and individual control archetypes exercised, is something that has not been alluded to in existing literature to a great extent.

The broad applicability of results control based performance measurement systems, regardless of low cost competitive strategy (Sandino, 2007), explains the lack of significant affect in results control model.

\subsubsection{Differentiation competitive strategy}

The coefficient for differentiation competitive strategy is positive and marginally statistically significant in the degree of control model (coefficient: $0.138, p$-value: 0.057 ), opposite to 
predictions and therefore not supporting Hypothesis 3. Further, the coefficient for differentiation competitive strategy is only significant and positive for the arm's length regression model (coefficient: $0.284, p$-value: 0.000 ). For the remaining four control archetype regression models, the differentiation competitive strategy coefficient is insignificant.

There are a range of facets associated with differentiation competitive strategies relating to new product development, brand identification, innovative marketing techniques, control of distribution channels, and advertising (Dess \& Davis, 1984; Langfield-Smith, 1997), consistent with our measurement of this variable. Such diversity means the effect on control exercised is difficult to examine. However, it is clear that differentiation competitive strategy certainly drives greater use of arm's length control and a potential explanation for this relates to the context of controlling WOFS operations at a distance. There is little doubt in this organisational context that high uncertainty and ex-post information asymmetry are likely (Birkinshaw, et al., 2001; Williamson, 1979). A market based approach to benchmarking performance targets, measurement, evaluation and rewards may be an appropriate means of dealing with the high uncertainty and ex-post information asymmetry faced. In this case headquarters are not exposed to the potential bounded rationality related pitfalls of internal benchmarking or opportunistic motives of WOFS management concerning performance evaluation. The positive and significant differentiation competitive strategy coefficient in the arm's length control model is therefore not what we initially expect, but is nonetheless a logical finding.

\subsection{Corporate embeddedness}

The coefficient for corporate embeddedness is positive and statistically significant in the degree of control model (coefficient: 0.191, p-value: 0.010), supporting Hypothesis 4. This indicates corporate embeddedness is associated with a higher degree of control. The 
corporate embeddedness construct is positive and statistically significant in the results, action and boundary control archetype models, but insignificant in the arm's length and exploratory control archetype models.

Reviewing the definition of corporate embeddedness provides some insight into the reasons why this factor is significantly and positively associated with some control archetypes and not others. High corporate embeddedness means there are significant synergies between entities within the MNC (Andersson \& Forsgren, 1996). Based on Speklé's (2001) conceptualisation of results control, it is likely that headquarters are in a far better position to exercise this control archetype due to the common performance expectations between entities controlled. In addition, the common processes and operational activities throughout a corporation where entities are highly corporately embedded is likely to fit closely with the possible use of action and boundary control archetypes, again consistent with the conceptualisations of Speklé (2001). These associations appear to be clearly driven by the lower levels of uncertainty and ex-post information as a result of high corporate embeddedness. In contrast, the appropriateness of arm's length control and exploratory control may be driven by other WOFS specific characteristics such as competitive strategy and stage of development (Chenhall, 2003). This may explain why no significant corporate embeddedness coefficients are observed in the arm's length and exploratory control models.

\subsection{External embeddedness}

The coefficient for external embeddedness is positive and marginally statistically significant in the degree of control model (coefficient: 0.122, p-value: 0.097 ), counter to predictions and therefore not supporting Hypothesis 5. Further, the coefficient for external embeddedness is only marginally significant (at the $10 \%$ level), and positive for the arm's length and action control regression models. 
Based on the definition of external embeddedness, highly externally embedded WOFS operations are adapted to a great extent to entities within the context they are located (Håkansson \& Snehota, 1995). This suggests that WOFS performance is very much dependent on general conditions all entities and relevant stakeholders face in such a context. The use of relative and market based performance assessment in such a context is therefore relevant and aligns most closely with Speklé's (2001) conceptualisation of the arm's length control archetype. The significant effect of external embeddedness concerning action control suggests headquarters want to maintain some relatively direct control at a distance, possibly to minimise risk exposure from outside the firm. Despite the challenges associated with controlling at a distance, particularly the high levels of uncertainty and ex-post information asymmetry expected where external embeddedness is high, it still seems headquarters may consider the use of arm's length and action control in this context as appropriate; however, the marginal significance of the coefficients needs to be noted. Whether these control archetype choices have favourable effects on performance is something that needs to be considered.

Given the external embeddedness variable is insignificant in all regression models, with the exception of arm's length and action control models, it appears other variables and characteristics of WOFS operations have a more substantial effect on the control headquarters exercise. In particular factors such as low cost competitive strategies and corporate embeddedness have far more substantial effects on WOFS operations and consequently headquarters' control choices (Andersson \& Forsgren, 1996; Chenhall, 2003). This is not to say that external embeddedness is not important to WOFS viability, but it is one of many significant factors relating to subsidiary operations. 


\subsection{Summary of Model 1 results}

Our results indicate corporate strategy, low cost competitive strategy and corporate embeddedness have substantial and significant effects on the degree of control exercised by headquarters. In contrast, differentiation competitive strategy and external embeddedness have much narrower and distinct effects on the control exercised; in particular there is greater focus on arm's length control in the presence of these contingent factors associated with more problematic contexts (as defined by activity trait levels expected). The focus on arm's length control appears to be associated with the usefulness of market based benchmarks in more problematic contexts.

\subsection{Sensitivity testing}

Given the size of our sample, the ability to split the sample for the purpose of sensitivity testing is limited. However, we did exclude different segments of our sample and reran the regressions to examine the sensitivity of our results. First, we excluded the lowest $10 \%$ of firms according to size (equivalent to 15 or less employees), then the highest $10 \%$ (equivalent to 5,000 or more employees). Second, we excluded firms in industries, in turn, that account for $10 \%$ or more of the sample (manufacturing, mining, professional services and wholesale trade). While the composition of firm industry involvement in our sample is consistent with industry involvement generally in Australia, these exclusions allowed us to check for industry affects. Third, it is widely acknowledged that region can affect choice of MCS (Chenhall, 2003); therefore we exclude each region, in turn. The three sets of sensitivity tests (based on size, industry and location exclusions) are largely consistent with the results for the regression models reported in Table $4^{6}$ and accordingly appear robust.

\footnotetext{
${ }^{6}$ In the interests of conserving the length of this paper, and due to the consistency of results with those reported in Table 4, we have not tabled these results in this paper. These results are available from the authors upon request.
} 
We run the regression models with the inclusion of activity trait independent variables (uncertainty, asset specificity, and ex-post information asymmetry), consistent with the variables examined in Giacobbe et al. (2016). The implications of the contingent factors we examine in this study on control (both the degree of control and individual archetypes) remains consistent with the results we report in Table $4^{6}$, indicating they have important and unique effects on control exercised - this relates to the unique combinations of activity traits (consistent with TCE theory adopted in this study) and factor specific considerations. This reaffirms this study has an important value add beyond existing research. Further, the implications of activity traits on control archetypes remain consistent with prior research and the VIF statistics indicate multicollinearity is not a concern.

\subsection{Additional testing}

As previously discussed, prior testing of Speklé's (2001) theory indicates headquarters exercise combinations of different control archetypes, affecting different degrees of control; this is consistent with dependent variable measurement. However, Speklé's (2001) original theory refers to control choices based on individual and exclusive control archetype choices. Therefore, it is important to examine whether the factors analysed in this study drive the exclusive selection of these control choices, as an alternative examination, and accordingly provide evidence of the appropriateness of the main analysis in this paper. To test whether exclusive control archetype selection is determined by the contingent factors, we run the following multinominal logistic regression (Model 2):

CONTROL_ARCHETYPE_MAX ${ }_{i}=\alpha_{0}+\alpha_{1} C O R P \_S T R A T E G Y_{i}+$ $\alpha_{2} L O W C O S T_{-} S T R A T E G Y_{i}+\alpha_{3} D I F F_{-} S T R A T E G Y_{i}+\alpha_{4} C O R P \_E M B E D_{i}+\alpha_{5} E X T_{-} E M B E D_{i}$ $+\alpha_{6} S I Z E_{i}+\varepsilon_{i}$ 
where:

CONTROL_ARCHETYPE_MAX: Classifies which of the five control archetypes headquarters exercise. The classification is based on which of the five control archetypes headquarters exercise to the greatest extent.

All independent variables are consistent with Model 1.

The results for the multinominal logistic regressions are presented below in Table 5 .

[INSERT TABLE 5 HERE]

While the chi-squares are statistically significant, the percentage of control archetypes classified is very low in some cases ( $4.4 \%$ for both arm's length and action control) and many of the independent variable coefficients are insignificant. The results of multinominal logistic regression indicate there is very limited evidence headquarters exercise exclusive control archetypes, as predicted by Speklé (2001), according to the factors we examine in this study. Therefore, these results do not provide any substantial insight into the control exercised by headquarters beyond the regression analysis we conduct based on Model 1.

We also conduct as number of further related tests. We use dummy variable based contingent factor variables, based on relative high and low levels, for the purpose of the multinominal logistic regression (Model 2) independent variables. We run a binary logistic regression (based on Model 2) and replace the dependent variable with a dummy variable measuring whether the control archetype is the primary one exercised by headquarters. The results for all these further tests indicate the statistical significance of the independent coefficients is generally very low. ${ }^{7}$ Accordingly, the results based on Mode1 1 and presented in Table 4

\footnotetext{
${ }^{7}$ In the interest of conserving the length of this paper, we have not tabled these results, instead tabling the main OLS regression results (Table 4) and main alternative set of tests (Table 5). These results are available from the authors upon request.
} 
appear to capture the effects of the contingent factors on control exercised to the greatest extent.

\section{Conclusion}

We examine the implications of the WOFS viability related contingent factors on the control headquarters exercise through a TCE approach. We draw on prior literature given the potential of more comprehensive control conceptualisations to assist in better understanding control exercised; in particular, Giacobbe et al. (2016) find that Speklé (2001) TCE based control conceptualisations are valid representations of headquarters' control choices, but are exercised in combination together. Our investigation is motivated by both the importance of WOFS operations and the continuing challenges of such entities from MNC headquarters' perspective (Cuypers \& Martin, 2010; Vachani, 2005; White, et al., 2014).

We find that contingent factors related to subsidiary viability do, to varying extents, affect the control headquarters exercise in the context of WOFS operations. Some factors such as corporate strategy, low cost competitive strategy and corporate embeddedness, significantly affect the overall degree of control exercised; this is consistent with the effect on individual control archetypes exercised, largely supporting our hypotheses. This is also consistent with prior literature, indicating headquarters exercise a higher degree of control, overall, given the context of controlling WOFS operations at a distance (Giacobbe, et al., 2016). However, other factors, such as differentiation competitive strategies and external embeddedness, are only marginally significantly associated with the overall degree of control exercised, consistent with only marginally significant effects on one or two control archetypes exercised in each case, in particular arm's length control. This suggests these factors may have more distinct and narrower implications on control choices exercised, in line with the predictions of Speklé (2001) original TCE theory of management control. 
There are a number of limitations and future research opportunities associated with this study. First, our study was limited to 159 complete responses. The sensitivity testing we conduct indicates our main results are robust; however, future replications, including those where headquarters are in different geographical locations, would be beneficial in further confirming the robustness of our findings. Second, while the viability related contingent factors examined explain a more substantial variation in control exercised than prior studies, there is certainly more scope to examine other factors affecting control exercised. Finally, extending the implications of this research in terms of the performance implications of different control exercised, given the viability related contingent factors, appears an important avenue of future research There is significant work to be done in this area and a case based approach may be appropriate to first investigate the relevant performance dimensions, possibly from headquarters' perspective, before examination through an empirical approach. 


\section{QUESTIONNAIRE ON FOREIGN SUBSIDIARIES}

\section{Purpose of this survey}

The purpose of this survey is to investigate how the head office of Australian companies manage wholly (100\%) owned foreign subsidiaries. This information will assist in understanding the effective management and performance of wholly owned foreign subsidiaries.

\section{Who is conducting this survey? $<$ Removed for blind review>}

\section{Instructions}

If your company wholly (100\%) owns more than one foreign subsidiary, please choose one and answer this questionnaire with respect to this subsidiary. If your company is involved in multiple wholly owned foreign subsidiaries and you would like to complete more than one questionnaire, please let me know and I will send you additional copies. If you wish to refer this questionnaire to someone else in your company, please do so or contact me and I will forward the questionnaire to them. If your company does not own foreign subsidiaries, please indicate this by ticking the relevant box in the enclosed postcard and return it to us.

\section{Confidentiality}

Your answers to this questionnaire are completely anonymous. To let us know you have returned this questionnaire, please return the enclosed postcard separately in the mail so no reminder questionnaire is sent to you.

\section{Thank you}

By returning the enclosed postcard with your details we will send you an executive report detailing the research findings and other outcomes of this study.

\section{Returning this questionnaire}

Please return this questionnaire in the reply paid envelope within 14 days.

\section{Help available}

$<$ Removed for blind review> 


\section{$\rightarrow$ PLEASE START HERE}

\section{Answer questions 1 to 4 with respect to your company}

1. How many years have you worked for your company? years

2. What is your current position?

3. How many people does your company employ:
a. In Australia:
b. Overseas:

4. Indicate whether your company is involved in:

a. International joint ventures

b. Exporting to foreign countries

Yes

No

$\square$

The remainder of this survey is about your company's involvement with a wholly (100\%) owned foreign subsidiary. Please note in the remainder of this survey "head office" refers to the Australian based head office of your company.

5. Please provide the following information about the foreign subsidiary (If your company wholly owns more than one foreign subsidiary, answer the questions in this survey with respect to the one of your choice):
a. Location (country):
b. Year of formation:
c. Number of people employed at subsidiary:
d. Number of expatriates (personnel from head office) employed at subsidiary:

6. Please tick the category or categories for the industry in which your company and your foreign subsidiary are principally involved (Please tick as many boxes as applicable):

\begin{tabular}{llcc} 
& & Your Company & Foreign subsidiary \\
\hline a. & Agriculture, Forestry and Fishing & $\square$ \\
\hline b. & Mining & $\square$ & $\square$ \\
\hline c. & Manufacturing & $\square$ & $\square$ \\
\hline d. & Electricity, Gas, Water and Waste Services & $\square$ & $\square$ \\
\hline e. & Construction & $\square$ & $\square$ \\
\hline f. & Wholesale Trade & $\square$ & $\square$ \\
\hline g. & Retail Trade & $\square$ & $\square$ \\
\hline h. & Accommodation and Food Services & $\square$ & $\square$ \\
\hline i. & Transport, Postal and Warehousing & $\square$ \\
\hline j. & Information Media and Telecommunications & $\square$ \\
\hline k. & Finance and Insurance Services & $\square$ & $\square$ \\
\hline l. & Rental, Hiring and Real Estate Services & $\square$ \\
\hline m. $\quad$ Professional, Scientific and Technical Services & $\square$ & $\square$ \\
\hline n. & Administrative and Support Services & $\square$ & $\square$ \\
\hline o. & Public Administration and Safety & $\square$ & $\square$ \\
\hline p. & Education and Training & $\square$ & $\square$ \\
\hline q. & Health Care and Social Assistance & $\square$ \\
\hline r. & Arts and Recreation Services & $\square$ & $\square$ \\
\hline s. $\quad$ Other Services & $\square$ & $\square$ \\
\hline
\end{tabular}


Answer question 7 using the scale below: (tick one box for each row)

\begin{tabular}{|c|c|c|c|c|}
\hline Significantly more & More & Same & Less & Significantly less \\
$\square 1$ & $\square 2$ & $\square 3$ & $\square 4$ & $\square 5$ \\
\hline
\end{tabular}

7. How much information does head office have compared to subsidiary personnel concerning the following factors?

\begin{tabular}{|c|c|c|c|c|c|c|}
\hline & & \multicolumn{2}{|c|}{$\begin{array}{l}\text { Significantly } \\
\text { more }\end{array}$} & & \multicolumn{2}{|c|}{$\begin{array}{r}\text { Significantly } \\
\text { less }\end{array}$} \\
\hline a. & Type of activities undertaken by subsidiary & $\square 1$ & $\square 2$ & $\square 3$ & $\square 4$ & $\square 5$ \\
\hline b. & Operational processes performed by subsidiary & $\square 1$ & $\square 2$ & $\square 3$ & $\square 4$ & $\square 5$ \\
\hline c. & Realisation of subsidiary performance potential & $\square 1$ & $\square 2$ & $\square 3$ & $\square 4$ & $\square 5$ \\
\hline d. & Impact of external factors on subsidiary performance & $\square 1$ & $\square 2$ & $\square 3$ & $\square 4$ & $\square 5$ \\
\hline e. & Understanding of what subsidiary has achieved & $\square 1$ & $\square 2$ & $\square 3$ & $\square 4$ & $\square 5$ \\
\hline
\end{tabular}

Answer questions 8 to 21 using the scale below: (tick one box for each row)

\begin{tabular}{|c|c|c|c|c|}
\hline $\begin{array}{c}\text { Strongly agree } \\
\square 1\end{array}$ & Agree & Neither agree nor disagree & Disagree & Strongly disagree \\
$\square 2$ & $\square 3$ & $\square 4$ & $\square 5$ \\
\hline
\end{tabular}

8. Indicate the extent you agree or disagree with the following statements from the perspective of head office:

\begin{tabular}{llcccc} 
& & \multicolumn{2}{c}{$\begin{array}{c}\text { Strongly } \\
\text { agree }\end{array}$} & \multicolumn{2}{c}{$\begin{array}{c}\text { Strongly } \\
\text { disagree }\end{array}$} \\
\hline a. $\quad$ Subsidiary goals are clearly defined & $\square 1$ & $\square 2$ & $\square 3$ & $\square 4$ & $\square 5$ \\
\hline b. Subsidiary goals provide clear direction to subsidiary personnel & $\square 1$ & $\square 2$ & $\square 3$ & $\square 4$ & $\square 5$ \\
\hline c. $\quad$ Subsidiary goals are easily explained to outsiders (e.g. customers) & $\square 1$ & $\square 2$ & $\square 3$ & $\square 4$ & $\square 5$ \\
d. $\quad$ Subsidiary goals are clear to everyone working in subsidiary & $\square 1$ & $\square 2$ & $\square 3$ & $\square 4$ & $\square 5$
\end{tabular}

9. Head office can predict developments which affect subsidiary operations in the region the subsidiary is located according to the following factors:

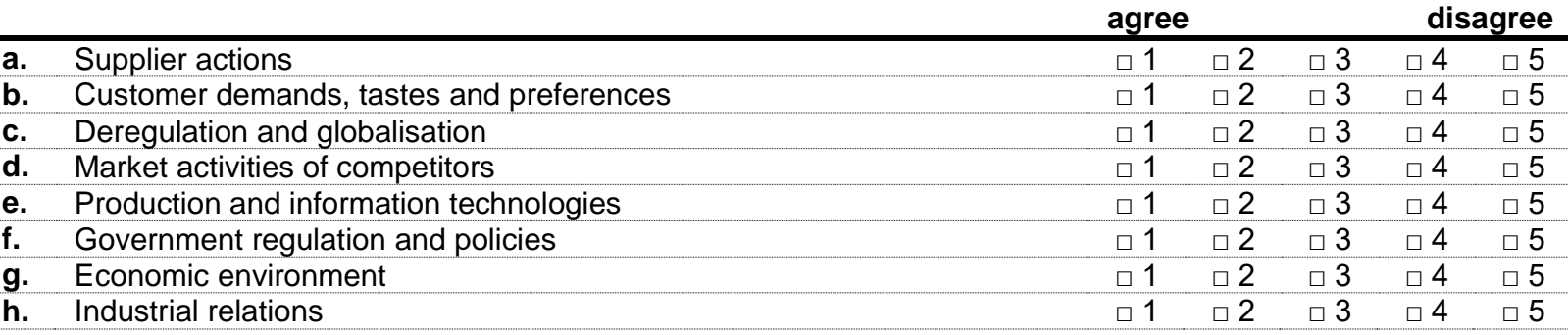

10. The following foreign subsidiary resources can be reallocated to alternative activities (for example, other subsidiaries or transferred back to head office) if subsidiary operations ceased:

\begin{tabular}{|c|c|c|c|c|c|c|}
\hline \multirow[b]{2}{*}{ a. } & \multirow[b]{2}{*}{ Skilled employees } & \multicolumn{2}{|c|}{$\begin{array}{l}\text { Strongly } \\
\text { agree }\end{array}$} & & \multicolumn{2}{|c|}{$\begin{array}{l}\text { Strongly } \\
\text { disagree }\end{array}$} \\
\hline & & $\square 1$ & $\square 2$ & $\square 3$ & $\square 4$ & $\square 5$ \\
\hline b. & Training programs & $\square 1$ & $\square 2$ & $\square 3$ & $\square 4$ & $\square 5$ \\
\hline c. & Physical assets (e.g. manufacturing and processing equipment) & $\square 1$ & $\square 2$ & $\square 3$ & $\square 4$ & $\square 5$ \\
\hline d. & Technological systems & $\square 1$ & $\square 2$ & $\square 3$ & $\square 4$ & $\square$ \\
\hline e. & Product customisation expertise & $\square 1$ & $\square 2$ & $\square 3$ & $\square 4$ & $\square 5$ \\
\hline f. & Branding rights & $\square 1$ & $\square 2$ & $\square 3$ & $\square 4$ & $\square 5$ \\
\hline & Reputational capital & $\square 1$ & $\square 2$ & $\square 3$ & $\square 4$ & $\square 5$ \\
\hline
\end{tabular}


11. Indicate the extent you agree or disagree with the following statements:

\begin{tabular}{|c|c|c|c|c|c|c|}
\hline \multirow[b]{2}{*}{ a. } & \multirow[b]{2}{*}{$\begin{array}{l}\text { The core area of business of both your subsidiary and your company's } \\
\text { global operations are related }\end{array}$} & \multicolumn{2}{|c|}{$\begin{array}{l}\text { Strongly } \\
\text { agree }\end{array}$} & & \multicolumn{2}{|c|}{$\begin{array}{l}\text { Strongly } \\
\text { disagree }\end{array}$} \\
\hline & & $\square 1$ & $\square 2$ & $\square 3$ & $\square 4$ & $\square 5$ \\
\hline b. & All the activities of your company's global operations are related & $\square 1$ & $\square 2$ & $\square 3$ & $\square 4$ & $\square 5$ \\
\hline c. & Your company's operations are involved in one line of business & $\square 1$ & $\square 2$ & $\square 3$ & $\square 4$ & $\square 5$ \\
\hline d. & Personnel from head office visit the subsidiary frequently & $\square 1$ & $\square 2$ & $\square 3$ & $\square 4$ & $\square 5$ \\
\hline e. & Subsidiary operations focus on a distinct activity & $\square 1$ & $\square 2$ & $\square 3$ & $\square 4$ & $\square 5$ \\
\hline f. & Focus of subsidiary operations is difficult to change & $\square 1$ & $\square 2$ & $\square 3$ & $\square 4$ & $\square 5$ \\
\hline & There is frequent communication between head office and subsidiary & $\square 1$ & $\square 2$ & $\square 3$ & $\square 4$ & $\square 5$ \\
\hline
\end{tabular}

12. The following factors are important to the competitiveness of the subsidiary relative to other companies in the region it operates:

\begin{tabular}{llcccc} 
& & \multicolumn{2}{c}{$\begin{array}{c}\text { Strongly } \\
\text { agree }\end{array}$} & $\begin{array}{c}\text { Strongly } \\
\text { disagree }\end{array}$ \\
\hline a. $\quad$ Operational efficiency & $\square 1$ & $\square 2$ & $\square 3$ & $\square 4$ & $\square 5$ \\
\hline b. $\quad$ Competitive pricing & $\square 1$ & $\square 2$ & $\square 3$ & $\square 4$ & $\square 5$ \\
\hline c. $\quad$ Procurement of product inputs & $\square 1$ & $\square 2$ & $\square 3$ & $\square 4$ & $\square 5$ \\
\hline d. $\quad$ Reducing production costs & $\square 1$ & $\square 2$ & $\square 3$ & $\square 4$ & $\square 5$ \\
\hline e. $\quad$ Minimisation of outside financing & $\square 1$ & $\square 2$ & $\square 3$ & $\square 4$ & $\square 5$ \\
\hline f. $\quad$ New product development & $\square 1$ & $\square 2$ & $\square 3$ & $\square 4$ & $\square 5$ \\
\hline g. $\quad$ Brand identification & $\square 1$ & $\square 2$ & $\square 3$ & $\square 4$ & $\square 5$ \\
\hline h. $\quad$ Innovative marketing techniques & $\square 1$ & $\square 2$ & $\square 3$ & $\square 4$ & $\square 5$ \\
\hline i. $\quad$ Control of distribution channels & $\square 1$ & $\square 2$ & $\square 3$ & $\square 4$ & $\square 5$ \\
\hline j. $\quad$ Advertising & $\square 1 \quad \square 2$ & $\square 3$ & $\square 4$ & $\square 5$ \\
\hline
\end{tabular}

13. The practices of subsidiary operations have changed or adapted over time due to relations with the following stakeholders:

Strongly

agree

\begin{tabular}{|c|c|c|c|c|c|c|}
\hline a. & Customers & $\square 1$ & $\square 2$ & $\square 3$ & $\square 4$ & $\square 5$ \\
\hline b. & Suppliers & $\square 1$ & $\square 2$ & $\square 3$ & $\square 4$ & $\square 5$ \\
\hline c. & Government organisations & $\square 1$ & $\square 2$ & $\square 3$ & $\square 4$ & $\square 5$ \\
\hline d. & Professional trade associations & $\square 1$ & $\square 2$ & $\square 3$ & $\square 4$ & $\square 5$ \\
\hline e. & Entities within your company (e.g. other subsidiaries) & $\square 1$ & $\square 2$ & $\square 3$ & $\square 4$ & $\square 5$ \\
\hline
\end{tabular}

14. Head office does the following concerning subsidiary operations:

\begin{tabular}{llcccc} 
& \multicolumn{2}{c}{$\begin{array}{c}\text { Strongly } \\
\text { agree }\end{array}$} & $\begin{array}{c}\text { Strongly } \\
\text { disagree }\end{array}$ \\
\hline a. $\quad$ Specifies subsidiary personnel's area of responsibility & $\square 1$ & $\square 2$ & $\square 3$ & $\square 4$ & $\square 5$ \\
\hline b. $\quad$ Sets guidelines specifying activities that are not to be engaged in & $\square 1$ & $\square 2$ & $\square 3$ & $\square 4$ & $\square 5$ \\
\hline c. $\quad$ Modifies targets in line with conditions subsidiary faces & $\square 1$ & $\square 2$ & $\square 3$ & $\square 4$ & $\square 5$ \\
\hline d. $\quad$ Uses documentation and manuals to direct subsidiary operations & $\square 1$ & $\square 2$ & $\square 3$ & $\square 4$ & $\square 5$ \\
\hline e. $\quad$ Conducts extensive training concerning compliances with policies & $\square 1$ & $\square 2$ & $\square 3$ & $\square 4$ & $\square 5$ \\
\hline f. $\quad$ Subjectively evaluates subsidiary performance & $\square 1$ & $\square 2$ & $\square 3$ & $\square 4$ & 4
\end{tabular}

15. Head office relies on internal audits to check subsidiary compliance with:

\section{Strongly}

agree

a. Policies and procedures

b. Guidelines specifying activities not to be engaged in

$\begin{array}{lllll}\square 1 & \square 2 & \square 3 & \square 4 & \square 5\end{array}$


16. The following budget roles for the foreign subsidiary are important:

\begin{tabular}{llcccc} 
& \multicolumn{2}{c}{$\begin{array}{c}\text { Strongly } \\
\text { agree }\end{array}$} & \multicolumn{2}{c}{$\begin{array}{c}\text { Strongly } \\
\text { disagree }\end{array}$} \\
\hline a. Specifies performance targets subsidiary required to achieve & $\square 1$ & $\square 2$ & $\square 3$ & $\square 4$ & $\square 5$ \\
\hline b. Provide guidance & $\square 1$ & $\square 2$ & $\square 3$ & $\square 4$ & $\square 5$ \\
\hline c. Set limits on what can be done & $\square 1 \quad \square 2$ & $\square 3$ & $\square 4$ & $\square 5$
\end{tabular}

17. Performance targets concerning foreign subsidiary operations are established in the following ways:

\section{Strongly}

agree

$\square 1 \quad \square 2$

a. Set at the beginning of the period

b. Set during the period
Strongly

disagree

18. When performance does not meet expectations head office intervenes in the activities of subsidiary management in the following ways:

Strongly

agree

a. Area of responsibility of subsidiary management changed

b. Decision making delegated to subsidiary management changed

c. Greater discussions between head office and subsidiary management concerning subsidiary operations

d. Senior subsidiary management replaced

$\square 1 \quad \square 2 \quad \square 3 \quad \square 4 \quad \square 5$

19. Indicate the extent you agree or disagree with the following statements at the subsidiary level:

\section{Strongly}

agree

a. Promotion of subsidiary personnel is linked to subsidiary performance

b. Violating policies set by head office has serious consequences for subsidiary personnel

c. Violating guidelines set by head office specifying activities not be engaged in has serious consequences for subsidiary personnel

$\square 1 \square 2 \square 3 \square 4 \square 5$

$\square 1 \quad \square 2 \quad \square 3 \quad \square 4 \quad \square 5$

$\square 1 \quad \square 2 \quad \square 3 \quad \square 4 \quad \square 5$

Strongly disagree

$\square 1 \square 2 \quad \square 3 \quad \square 4 \quad \square 5$

$\square 1 \quad \square 2 \quad \square 3 \quad \square 4 \quad \square 5$

$\square 1 \quad \square 2 \quad \square 3 \quad \square 4 \quad \square 5$

20. Head office is involved in the recruitment and training of subsidiary personnel in the following ways:

a. Selection of personnel determined by head office

b. Subsidiary management are trained by head office before they commence in their roles at the subsidiary

c. Ongoing training of personnel is provided by head office

d. Head office is strongly committed to development of personnel

\section{Strongly}

agree

Strongly disagree

$\begin{array}{lllll}\square & \square 2 & \square 3 & \square & \square 5\end{array}$

$\square 1 \quad \square 2 \quad \square 3 \quad \square 4 \quad \square 5$

$\square 1 \quad \square 2 \quad \square 3 \quad \square 4 \quad \square 5$

$\square 1 \square 2 \quad \square 3 \quad \square 4 \quad \square 5$

21. The following are used by head office to influence subsidiary personnel behaviour:

Strongly

agree

a. Communication of corporate values

b. Communication of codes of conduct

c. Frequent transfer of head office managers to the subsidiary

disagree

$\square 1 \quad \square 2 \quad \square 3 \quad \square 4 \quad \square 5$

$\square 1 \quad \square 2 \quad \square 3 \quad \square 4 \quad \square 5$

$\square 1 \quad \square 2 \quad \square 3 \quad \square 4 \quad \square 5$




\section{Answer question 22 using the scale below: (tick one box for each row)}

\begin{tabular}{|c|c|c|c|c|}
\hline $\begin{array}{c}100 \% \text { head office's } \\
\text { responsibility }\end{array}$ & $\begin{array}{c}\text { Mostly head office's } \\
\text { responsibility }\end{array}$ & $\begin{array}{c}\text { Shared } \\
\text { responsibility }\end{array}$ & $\begin{array}{c}\text { Mostly subsidiary } \\
\text { management's responsibility }\end{array}$ & $\begin{array}{c}100 \% \text { subsidiary } \\
\text { management's responsibility } \\
\square 1\end{array}$ \\
$\square 2$ & $\square 3$ & $\square 4$ & $\square 5$ \\
\hline
\end{tabular}

22. Indicate whether head office and/or subsidiary management is responsible for the decision making process in the following areas:

\begin{tabular}{|c|c|c|c|c|c|c|}
\hline & & $\begin{array}{l}100 \\
\text { offi }\end{array}$ & ead & & & $\begin{array}{l}\text { diary } \\
\text { ment }\end{array}$ \\
\hline a. & Long-term planning concerning subsidiary operations & $\square 1$ & $\square 2$ & $\square 3$ & $\square 4$ & $\square 5$ \\
\hline b. & Special business cases undertaken by subsidiary & $\square 1$ & $\square 2$ & $\square 3$ & $\square 4$ & $\square 5$ \\
\hline c. & Tasks performed by subsidiary & $\square 1$ & $\square 2$ & $\square 3$ & $\square 4$ & $\square 5$ \\
\hline d. & Standard operating procedures/work instructions for subsidiary & $\square 1$ & $\square 2$ & $\square 3$ & $\square 4$ & $\square 5$ \\
\hline e. & Guidelines and policies guiding subsidiary operations & $\square 1$ & $\square 2$ & $\square 3$ & $\square 4$ & $\square 5$ \\
\hline f. & Target setting for subsidiary & $\square 1$ & $\square 2$ & $\square 3$ & $\square 4$ & $\square 5$ \\
\hline g. & Evaluation of subsidiary performance & $\square 1$ & $\square 2$ & $\square 3$ & $\square 4$ & $\square 5$ \\
\hline h. & Reward allocation to subsidiary personnel & $\square 1$ & $\square 2$ & $\square 3$ & $\square 4$ & $\square 5$ \\
\hline
\end{tabular}

Answer questions 23 to 27 using the scale below: (tick one box for each row)

\begin{tabular}{|c|c|c|c|c|}
\hline Very high & High & Moderate & Low & Not at all \\
$\square 1$ & $\square 2$ & $\square 3$ & $\square 4$ & $\square 5$ \\
\hline
\end{tabular}

23. Indicate the degree of similarity between the subsidiary and all other entities owned by your company concerning practices in the following areas:

\begin{tabular}{|c|c|c|c|c|c|c|}
\hline a. & Human resources & $\square 1$ & $\square 2$ & $\overline{\square 3}$ & $\square 4$ & $\square 5$ \\
\hline b. & Training programs & $\square 1$ & $\square 2$ & $\square 3$ & $\square 4$ & $\square 5$ \\
\hline c. & Information system & $\square 1$ & $\square 2$ & $\square 3$ & $\square 4$ & $\square 5$ \\
\hline d. & Purchase and ordering system & $\square 1$ & $\square 2$ & $\square 3$ & $\square 4$ & $\square 5$ \\
\hline e. & Reporting system & $\square 1$ & $\square 2$ & $\square 3$ & $\square 4$ & $\square 5$ \\
\hline
\end{tabular}

24. What importance does head office place on the following targets concerning subsidiary operations?

\begin{tabular}{|c|c|c|c|c|c|c|}
\hline & & \multicolumn{3}{|c|}{ Very high } & \multicolumn{2}{|c|}{ Not at all } \\
\hline a. & Return targets (e.g. return on investment/assets) & $\square 1$ & $\square 2$ & $\square 3$ & $\square 4$ & $\square 5$ \\
\hline b. & Profit targets (e.q. net profit, gross profit) & $\square 1$ & $\square 2$ & $\square 3$ & $\square 4$ & $\square 5$ \\
\hline c. & Sales targets & $\square 1$ & $\square 2$ & $\square 3$ & $\square 4$ & $\square 5$ \\
\hline d. & Cash flow targets & $\square 1$ & $\square 2$ & $\square 3$ & $\square 4$ & $\square 5$ \\
\hline e. & Customer targets (e.g. market share, customer satisfaction) & $\square 1$ & $\square 2$ & $\square 3$ & $\square 4$ & $\square 5$ \\
\hline f. & Internal process targets (e.g. processing time, efficiency ratings) & $\square 1$ & $\square 2$ & $\square 3$ & $\square 4$ & $\square 5$ \\
\hline g. & Learning targets (e.g. employee development, $R \& D$ outcomes) & $\square 1$ & $\square 2$ & $\square 3$ & $\square 4$ & $\square 5$ \\
\hline h. & Market benchmarks & $\square 1$ & $\square 2$ & $\square 3$ & $\square 4$ & $\square 5$ \\
\hline i. & Internal benchmarks & $\square 1$ & $\square 2$ & $\square 3$ & $\square 4$ & $\square 5$ \\
\hline
\end{tabular}

25. What importance does head office place on the following when monitoring subsidiary performance?

\begin{tabular}{|c|c|c|c|c|c|c|}
\hline & & \multicolumn{2}{|c|}{ Very high } & & \multicolumn{2}{|c|}{ Not at all } \\
\hline a. & Achievement of performance target(s) & $\square 1$ & $\square 2$ & $\square 3$ & $\square 4$ & $\square 5$ \\
\hline b. & Variance between budget and actual performance & $\square 1$ & $\square 2$ & $\square 3$ & $\square 4$ & $\square 5$ \\
\hline c. & Market benchmarks versus actual performance & $\square 1$ & $\square 2$ & $\square 3$ & $\square 4$ & $\square 5$ \\
\hline d. & Line items in financial accounts (e.g. revenues, expenses, profit) & $\square 1$ & $\square 2$ & $\square 3$ & $\square 4$ & $\square 5$ \\
\hline e. & Unexpected news concerning subsidiary performance & $\square 1$ & $\square 2$ & $\square 3$ & $\square 4$ & $\square 5$ \\
\hline
\end{tabular}


26. What importance does head office place on the following when evaluating subsidiary performance?

Very high

\begin{tabular}{|c|c|c|c|c|c|c|}
\hline & & & \\
\hline a. & Achievement of performance target(s) & $\square 1$ & $\square 2$ & $\square 3$ & $\square 4$ & $\square 5$ \\
\hline b. & Variance between budget versus actual performance & $\square 1$ & $\square 2$ & $\square 3$ & $\square 4$ & $\square 5$ \\
\hline c. & Market benchmarks versus actual performance & $\square 1$ & $\square 2$ & $\square 3$ & $\square 4$ & $\square 5$ \\
\hline d. & Compliance with policies and procedures & $\square 1$ & $\square 2$ & $\square 3$ & $\square 4$ & $\square 5$ \\
\hline e. & Professional development of managers & $\square 1$ & $\square 2$ & $\square 3$ & $\square 4$ & $\square 5$ \\
\hline f. & Long-term sustained performance & $\square 1$ & $\square 2$ & $\square 3$ & $\square 4$ & $\square 5$ \\
\hline g & Contribution to overall performance of your company & $\square 1$ & $\square 2$ & $\square 3$ & $\square 4$ & $\square 5$ \\
\hline
\end{tabular}

27. What importance does head office place on the following when rewarding subsidiary management?

\begin{tabular}{|c|c|c|c|c|c|c|}
\hline & & \multicolumn{3}{|c|}{ Very high } & \multicolumn{2}{|c|}{ Not at all } \\
\hline a. & Achievement of performance target(s) & $\square 1$ & $\square 2$ & $\square 3$ & $\square 4$ & $\square 5$ \\
\hline b. & Variance between budget and actual performance & $\square 1$ & $\square 2$ & $\square 3$ & $\square 4$ & $\square 5$ \\
\hline c. & Market benchmarks versus actual performance & $\square 1$ & $\square 2$ & $\square 3$ & $\square 4$ & $\square 5$ \\
\hline d. & Long-term performance & $\square 1$ & $\square 2$ & $\square 3$ & $\square 4$ & $\square 5$ \\
\hline e. & Subsidiary specific performance & $\square 1$ & $\square 2$ & $\square 3$ & $\square 4$ & $\square 5$ \\
\hline f. & Corporation wide performance & $\square 1$ & $\square 2$ & $\square 3$ & $\square 4$ & $\square$ \\
\hline g. & Subjective performance judgement by head office & $\square 1$ & $\square 2$ & $\square 3$ & $\square 4$ & $\square 5$ \\
\hline
\end{tabular}

\section{Answer questions 28 and 29 using the scales provided: (tick one box for each row)}

28. Indicate the satisfaction of head office with the performance of the wholly owned foreign subsidiary according to the following factors (Please tick one box for each row):

$\begin{array}{cccccc}\begin{array}{c}\text { Extremely } \\ \text { satisfied }\end{array} & \begin{array}{c}\text { Satisfi } \\ \text { ed }\end{array} & \begin{array}{c}\text { Neither } \\ \text { satisfied } \\ \text { nor } \\ \text { dissatisfied }\end{array} & \begin{array}{c}\text { Dissatisfie } \\ \text { d }\end{array} & \begin{array}{c}\text { Extremely } \\ \text { dissatisfie } \\ \text { d }\end{array} & \begin{array}{c}\text { Not } \\ \text { relevan } \\ \text { t }\end{array} \\ & & & & \end{array}$

\begin{tabular}{|c|c|c|c|c|c|c|c|}
\hline a. & Profitability & $\square$ & $\square$ & $\square$ & $\square$ & $\square$ & $\square$ \\
\hline b. & Sales volume & $\square$ & $\square$ & $\square$ & $\square$ & $\square$ & $\square$ \\
\hline c. & Market share & $\square$ & $\square$ & $\square$ & $\square$ & $\square$ & $\square$ \\
\hline d. & Productivity & $\square$ & $\square$ & $\square$ & ㅁ & $\square$ & $\square$ \\
\hline e. & Adapting to a foreign market & $\square$ & $\square$ & $\square$ & $\square$ & $\square$ & $\square$ \\
\hline f. & Ability to adopt innovation & $\square$ & $\square$ & $\square$ & $\square$ & $\square$ & $\square$ \\
\hline g. & Learning about unfamiliar market & $\square$ & $\square$ & $\square$ & $\square$ & $\square$ & $\square$ \\
\hline h. & Learning about new technology & $\square$ & $\square$ & $\square$ & $\square$ & $\square$ & $\square$ \\
\hline i. & Product quality & $\square$ & $\square$ & $\square$ & $\square$ & $\square$ & $\square$ \\
\hline j. & Customer satisfaction & $\square$ & $\square$ & $\square$ & $\square$ & $\square$ & $\square$ \\
\hline k. & Corporate citizenship & $\square$ & $\square$ & $\square$ & $\square$ & $\square$ & $\square$ \\
\hline
\end{tabular}

29. In general, how satisfied is head office with the overall performance of the wholly owned foreign subsidiary?

$\begin{array}{cccc}\text { Extremely satisfied } \quad \text { Satisfied } & \begin{array}{c}\text { Neither satisfied nor } \\ \text { dissatisfied }\end{array} & \text { Dissatisfied Extremely dissatisfied }\end{array}$

$\square$

$\square$ $\square$

$\square$

$\square$

Thank you for taking the time to complete this questionnaire. Your assistance is very much appreciated. 


\section{$\underline{\text { Appendix B }}$}

\section{Table B.1 - Indicators of control archetypes}

\begin{tabular}{|c|c|c|c|c|c|c|c|c|c|}
\hline \multicolumn{2}{|c|}{ Dimensions } & & Control archetype indicators & Survey questions & $\begin{array}{c}\text { Arm's length } \\
\text { control }\end{array}$ & $\begin{array}{l}\text { Results oriented } \\
\text { machine control }\end{array}$ & $\begin{array}{l}\text { Action oriented } \\
\text { machine control }\end{array}$ & $\begin{array}{c}\text { Boundary } \\
\text { control }\end{array}$ & $\begin{array}{c}\text { Exploratory } \\
\text { control }\end{array}$ \\
\hline \multirow{4}{*}{\multicolumn{2}{|c|}{ Structure }} & 1 & Accountability/responsibilities defined & $14 \mathrm{a}$ & & $\checkmark$ & $\checkmark$ & & \\
\hline & & 2 & Autonomy extended to subsidiary management & $22 \mathrm{a}-\mathrm{e}$ & $\checkmark$ & $\checkmark$ & $\checkmark$ (reversed) & $\checkmark$ & $\checkmark$ \\
\hline & & 3 & HQ management by exception & $18 \mathrm{a}-\mathrm{d}$ & $\checkmark$ & $\checkmark$ & & & \\
\hline & & 4 & $\begin{array}{l}\text { Transparency of information flow (between HQ } \\
\text { and subsidiary) }\end{array}$ & $11 \mathrm{~g}$ & & & & & $\checkmark$ \\
\hline \multirow{8}{*}{ Standardisation } & \multirow{3}{*}{ Action } & 5 & Boundaries delineated & $14 \mathrm{~b}$ & & & & $\checkmark$ & \\
\hline & & 6 & Codification of actions (rules \& instructions) & $14 d, e$ & & & $\checkmark$ & & \\
\hline & & 7 & Standardised systems & $23 a-e$ & & & $\checkmark$ & & \\
\hline & \multirow{5}{*}{ Targets } & 8 & Codification of targets (internally determined) & $(24 a-g, 24 i, 16 a, 17 a)$ & & $\checkmark$ & & & \\
\hline & & 9 & Flexibility of targets & $22 \mathrm{f}, 14 \mathrm{c}$ & & $\checkmark($ reversed $)$ & & & $\checkmark$ \\
\hline & & 10 & Broad HQ performance expectations & $16 \mathrm{~b}$ & & & & & $\checkmark$ \\
\hline & & 11 & Emergent HQ performance expectations & $17 \mathrm{~b}$ & & & & & $\checkmark$ \\
\hline & & 12 & Set limits on activities & $16 \mathrm{c}$ & & & & $\checkmark$ & \\
\hline \multirow{6}{*}{\multicolumn{2}{|c|}{$\begin{array}{l}\text { Monitoring \& performance } \\
\text { evaluation }\end{array}$}} & 13 & $\begin{array}{l}\text { Adherence to codified actions (policies and } \\
\text { procedures) monitored }\end{array}$ & $15 \mathrm{a}, 26 \mathrm{~d}$ & & & $\checkmark$ & & \\
\hline & & 14 & Monitoring \& evaluation based on codified targets & $25 a-b, d, 11 d, 26 a-b$ & & $\checkmark$ & & & \\
\hline & & 15 & $\begin{array}{l}\text { Monitoring \& evaluation according to market } \\
\text { benchmarks }\end{array}$ & $24 \mathrm{~h}, 25 \mathrm{c}, 26 \mathrm{c}$ & $\checkmark$ & & & & \\
\hline & & 16 & Long-term performance assessment & $26 \mathrm{e}, 26 \mathrm{f}-\mathrm{g}$ & & & & & $\checkmark$ \\
\hline & & 17 & Subjectivity in performance evaluation & $22 \mathrm{~g}, 14 \mathrm{f}$ & & & & & $\checkmark$ \\
\hline & & 18 & $\begin{array}{l}\text { HQ periodically checking compliance with } \\
\text { boundaries }\end{array}$ & $15 b, 26 d$ & & & & $\checkmark$ & \\
\hline \multirow{6}{*}{\multicolumn{2}{|c|}{ Rewards }} & 19 & $\begin{array}{l}\text { Punishment for not complying with codified } \\
\text { actions }\end{array}$ & $19 \mathrm{~b}$ & & & $\checkmark$ & & \\
\hline & & 20 & Rewards based on codified evaluation & $27 a-b$ & & $\checkmark$ & & & \\
\hline & & 21 & $\begin{array}{l}\text { Rewards tied to market based performance } \\
\text { evaluation }\end{array}$ & $27 \mathrm{c}$ & $\checkmark$ & & & & \\
\hline & & 22 & Reward through promotion & $27 d, 19 a$ & & & & & $\checkmark$ \\
\hline & & 23 & Subjectivity in reward determination & $27 \mathrm{e}, 22 \mathrm{~h}$ & & & & & $\checkmark$ \\
\hline & & 24 & Severe sanctions for crossing boundaries & $19 \mathrm{c}$ & & & & $\checkmark$ & \\
\hline
\end{tabular}




\section{Appendix C - Variable measurement validity}

Table C.1 - Factor loadings of construct indicators

\begin{tabular}{lc} 
Constructs & Rotated Factor \\
Indicators & Loading \\
\hline
\end{tabular}

Arm's length control*

Monitoring \& evaluation according to market benchmarks (MCI 15) 0.923

Rewards tied to market based performance evaluation (MCI 21) 0.923

Results oriented machine control*

$\begin{array}{ll}\text { Codifications of targets (MCI 8) } & 0.766\end{array}$

Monitoring \& evaluation based on codified targets (MCI 14) 0.883

$\begin{array}{ll}\text { Rewards based on codified evaluation (MCI 20) } & 0.847\end{array}$

Action oriented machine control*

$\begin{array}{lr}\text { Codification of actions (MCI 6) } & 0.776\end{array}$

$\begin{array}{ll}\text { Adherence to codified actions (MCI 13) } & 0.845\end{array}$

Punishment for not complying with codified actions (MCI 19) 0.755

Boundary control*

$\begin{array}{ll}\text { Boundaries delineated (MCI 5) } & 0.806\end{array}$

HQ periodically checking compliance with boundaries (MCI 18) 0.768

$\begin{array}{ll}\text { Severe sanctions for crossing boundaries (MCI 24) } & 0.769\end{array}$

\section{Exploratory control*}

Transparency of information flow (MCI 4) $\quad 0.680$

$\begin{array}{ll}\text { Flexibility of targets (MCI 9) } & 0.712\end{array}$

$\begin{array}{ll}\text { Broad HQ performance expectations (MCI 10) } & 0.673\end{array}$

$\begin{array}{ll}\text { Subjectivity in performance evaluation (MCI 17) } & 0.601\end{array}$

\section{Corporate strategy $^{\wedge}$}

Relatedness of subsidiary core business to company’s global operations (11a) 0.831

Relatedness of company's global operations (11b) 0.906

Company operations involved in one line of business (11c) 0.744

\section{Degree of control}

Arm's length control $\quad 0.528$

$\begin{array}{lr}\text { Results oriented machine control } & 0.675\end{array}$

$\begin{array}{lr}\text { Action oriented machine control } & 0.865\end{array}$

$\begin{array}{lr}\text { Boundary control } & 0.866\end{array}$

$\begin{array}{ll}\text { Exploratory control } & 0.727\end{array}$

Low cost competitive strategy ${ }^{\wedge}$

$\begin{array}{lr}\text { Operational efficiency (12a) } & 0.715\end{array}$

$\begin{array}{lr}\text { Procurement of product inputs (12c) } & 0.816\end{array}$

$\begin{array}{ll}\text { Reducing production costs }(12 \mathrm{~d}) & 0.891\end{array}$

Differentiation competitive strategy $^{\wedge}$

$\begin{array}{lr}\text { New product development (12f) } & 0.643\end{array}$

$\begin{array}{lr}\text { Brand identification (12g) } & 0.813\end{array}$

$\begin{array}{lr}\text { Innovative marketing techniques }(12 \mathrm{~h}) & 0.870\end{array}$

$\begin{array}{lr}\text { Control of distribution channels (12i) } & 0.778\end{array}$

$\begin{array}{lr}\text { Advertising (12j) } & 0.830\end{array}$

External embeddedness ${ }^{\wedge}$

$\begin{array}{lr}\text { Suppliers (13b) } & 0.722\end{array}$

$\begin{array}{ll}\text { Government organisations (13c) } & 0.731\end{array}$

$\begin{array}{ll}\text { Professional trade associations (13d) } & 0.798\end{array}$

*Refer to Table B.1 (Appendix B) for the survey questions applied at the basis of the control archetype indicators

${ }^{\wedge}$ Refer to Appendix A for the survey instrument relating to the indicators 
Table C.2 - Construct composite reliability

\begin{tabular}{lc}
\hline Construct & Cronbach's Alpha \\
\hline Arm's length control & 0.826 \\
Results oriented machine control & 0.775 \\
Action oriented machine control & 0.701 \\
Boundary control & 0.678 \\
Exploratory control & 0.584 \\
Degree of control & 0.759 \\
Corporate strategy & 0.695 \\
Low cost competitive strategy & 0.735 \\
Differentiation competitive strategy & 0.846 \\
External embeddedness & 0.611 \\
\hline
\end{tabular}


Table C.3 - Discriminant validity: Construct Spearman's correlations and square root of AVE on diagonal

\begin{tabular}{|c|c|c|c|c|c|c|c|c|c|c|}
\hline & $\begin{array}{l}\text { Arm's } \\
\text { length } \\
\text { control }\end{array}$ & $\begin{array}{l}\text { Results } \\
\text { control }\end{array}$ & $\begin{array}{l}\text { Action } \\
\text { control }\end{array}$ & $\begin{array}{l}\text { Boundary } \\
\text { control }\end{array}$ & $\begin{array}{l}\text { Exploratory } \\
\text { control }\end{array}$ & $\begin{array}{l}\text { Corporate } \\
\text { strategy }\end{array}$ & $\begin{array}{l}\text { Low cost } \\
\text { competitive } \\
\text { strategy }\end{array}$ & $\begin{array}{l}\text { Differentiation } \\
\text { competitive } \\
\text { strategy }\end{array}$ & $\begin{array}{l}\text { Corporate } \\
\text { embeddedness }\end{array}$ & $\begin{array}{l}\text { External } \\
\text { embeddedness }\end{array}$ \\
\hline Arm's length control & 0.923 & & & & & & & & & \\
\hline Results control & $0.383 * *$ & 0.833 & & & & & & & & \\
\hline Action control & $0.303 * * *$ & $0.407 * * *$ & 0.793 & & & & & & & \\
\hline Boundary control & $0.308 * * *$ & $0.407 * * *$ & $0.813 * * *$ & 0.781 & & & & & & \\
\hline Exploratory control & $0.132 *$ & $0.455 * * *$ & $0.531 * * *$ & $0.551 * * *$ & 0.668 & & & & & \\
\hline Corporate strategy & -0.057 & -0.107 & -0.095 & -0.120 & $-0.259 * * *$ & 0.688 & & & & \\
\hline Low cost competitive strategy & $0.270 * * *$ & $0.207 * * *$ & $0.305 * * *$ & $0.304 * * *$ & $0.192 * *$ & -0.068 & 0.657 & & & \\
\hline Differentiation competitive strategy & $0.345^{* * *}$ & $0.160 * *$ & 0.075 & 0.078 & 0.061 & -0.007 & $0.238 * * *$ & 0.625 & & \\
\hline Corporate embeddedness & $0.155^{*}$ & $0.259 * * *$ & $0.184 * *$ & $0.189 * *$ & 0.012 & 0.063 & 0.017 & 0.040 & 1.000 & \\
\hline External embeddedness & $0.230 * * *$ & $0.203 * *$ & $0.253 * * *$ & 0.116 & 0.129 & -0.016 & $0.150 *$ & 0.147 & $0.250 * * *$ & 0.564 \\
\hline
\end{tabular}

***Significant at the 0.01 level; **Significant at the 0.05 level; *Significant at the 0.10 level (two tailed) 


\section{Acknowledgements}

We would like to thank the survey respondents, who made this study possible. We would like to thank Martin Bugeja, Dan Dhaliwal, Francesco Giacobbe, Markus Granlund, Teemu Malmi, Ken Merchant, Gerhard Speckbacher, participants at the 2014 European Accounting Association conference and the participants at the 2015 UTS seminar series for their valuable comments and suggestions. We would also like to thank David Dugdale, David Marginson and the participants at the 2010 British Accounting Association Doctoral Colloquium for their valuable comments and suggestions during the early stages of this research. 


\section{$\underline{\text { References }}$}

Abdel-Kader, M., \& Luther, R. (2008). The Impact of Firm Characteristics on Management Accounting Practices: A UK-based Empirical Analysis. The British Accounting Review, 40, 2-27.

Abernethy, M. A., Bouwens, J., \& Lent, L. V. (2004). Determinants of control systems design in divisionalized firms. The Accounting Review, 79, 545-570.

Adler, R. W. (2011). Performance management and organizational strategy: How to design systems that meet the needs of confrontation strategy firms. The British Accounting Review, 43, 251-263.

Agbejule, A. (2005). The relationship between management accounting systems and perceived environmental uncertainty on managerial performance: A research note. Accounting and Business Research, 35, 295-305.

Anand, J., \& Singh, H. (1997). Asset redeployment, acquisitions and corporate strategy in declining industries. Strategic Management Journal, 18, 99-118.

Andersson, U., Bjorkman, I., \& Forsgren, M. (2005). Managing subsidiary knowledge creation: The effect of control mechanisms on local embeddedness. International Business Review, 14, 521-538.

Andersson, U., \& Forsgren, M. (1996). Subsidiary embeddedness and control in the multinational corporation. International Business Review, 5, 487-508.

Andersson, U., Forsgren, M., \& Holm, U. (2001). Subsidiary Embeddedness and Competence Development in MNCs - A Multi-Level Analysis. Organization Studies, 22, 10131034.

Andersson, U., Forsgren, M., \& Holm, U. (2002). The strategic impact of external networks: Subsidiary performance and competence development in the multinational corporation. Strategic Management Journal, 23, 979-996.

Andersson, U., Forsgren, M., \& Holm, U. (2007). Balancing Subsidiary Influence in the Federative MNC: A Business Network View. Journal of International Business Studies, 38, 802-818.

Argyres, N. (1995). Technology strategy, governance structure and interdivisional coordination. Journal of Economic Behavior and Organization, 28, 337-358.

Ashton, D., Beattie, V., Broadbent, J., Brooks, C., Draper, P., Ezzamel, M., Gwilliam, D., Hodgkinson, R., Hoskin, K., Pope, P., \& Stark, A. (2009). British research in accounting and finance (2001-2007): The 2008 research assessment exercise. The British Accounting Review, 41, 199-207.

Baliga, B. R., \& Jaeger, A. M. (1984). Multinational corporation: Control systems and delegation issues. Journal of International Business Studies, 25-40.

Berry, A. J., Coad, A. F., Harris, E. P., Otley, D. T., \& Stringer, C. (2009). Emerging themes in management control: A review of recent literature. The British Accounting Review, $41,2-20$.

Birkinshaw, J., Toulan, O., \& Arnold, D. (2001). Global account management in multinational corporations: Theory and evidence. Journal of International Business Studies, 32, 231-248.

Bonaglia, F., Goldstein, A., \& Mathews, J. A. (2007). Accelerated internationalization by emerging markets' multinationals: the case of the white goods sector. Journalof World Business, 42, 369-383.

Chandler, A. D. (1962). Strategy and structure. Cambridge, MA: M.I.T. Press.

Chandler, A. D. (1991). The functions of the HQ unit in the multibusiness firm. Strategic Management Journal, 12, 31-50. 
Chenhall, R. H. (2003). Management control systems design within its organizational context: findings from contingency-based research and directions for the future. Accounting, Organizations and Society, 28, 127-168.

Chenhall, R. H., \& Langfield-Smith, K. (1998). The Relationship Between Strategic Priorities, Management Techniques and Management Accounting: An Empirical Investigation Using a Systems Approach. Accounting, Organizations and Society, 23, 243-264.

Christensen, J., \& Kent, P. (2015). The decision to outsource risk management services. Accounting and Finance, Forthcoming.

Collis, D. J., \& Montgomery, C. A. (1997). Corporate strategy: Resources and the scope of the firm: Chicago: Irwin).

Cuypers, I. R. P., \& Martin, X. (2010). What makes and what does not make a real option? A study of international joint ventures. Journal of International Business Studies, 41, 47-69.

Dess, G. G., \& Davis, P. S. (1984). Porter's (1980) Generic strategies as determinants of strategic group membership and organizational performance. Academy of Management Journal, 27, 467-488.

Dillman, D. (2000). Mail and internet surveys: The tailored design method. New York ; Chichester: John Wiley.

Dimitratos, P., Liouka, I., \& Young, S. (2009). Regional location of multinational corporation subsidiaries and economic development contribution: Evidence from the UK. Journal of World Business, 44, 180-191.

Ditillo, A. (2004). Dealing with uncertainty in knowledge-intensive firms: The role of management control systems as knowledge integration mechanisms. Accounting, Organizations and Society, 29, 401-421.

Dunning, J. (1993). Multinational enterprise and the global economy: Reading (MA): Addison-Wesley.

Dunning, J. H. (2006). Comment on dragon multinationals: new players in 21st century globalisation. Asia Pacific Journal of Management, 23, 139-141.

Fornell, C., \& Larcker, D. F. (1981). Evaluating structural equation models with unobservable variables and measurement error. Journal of Marketing Research, 18, 39-50.

Forsgren, M., Pedersen, T., \& Foss, N. J. (1999). Accounting for the strengths of MNC subsidiaries: the case of foreign-owned firms in Denmark. International Business Review, 8, 181-196.

Freeland, R. F. (1996). The myth of the M-form? Governance, consent, and organizational change. American Journal of Sociology, 102, 483-527.

Ghoshal, S., Korine, H., \& Szulanski, G. (1994). Interunit communication in multinational Corporations. Management Science, 40, 96-110.

Giacobbe, F., \& Booth, P. (2009). Controlling international joint ventures: An investigation of australian parent partners. Australian Accounting Review, 19, 103-116.

Giacobbe, F., Matolcsy, Z., \& Wakefield, J. (2016). An investigation of wholly-owned foreign subsidiary control through transaction cost economics theory. Accounting and Finance, In Press.

Goold, M., Campbell, A., \& Alexander, M. (1994). How corporate parents add value to the stand-alone performance of their businesses. Business Strategy Review, 5, 33-55.

Goold, M., Campbell, A., \& Luchs, K. (1993). Strategies and styles revisited: 'Strategic control' is it tenable? Long Range Planning, 26, 54-61. 
Goold, M., \& Luchs, K. (2003). Why diversity? Four decades of management thinking. In D. O. Faulkner \& A. Campbell (Eds.), The Oxford handbook of strategy (pp. 17-42). Oxford: Oxford University Press.

Gupta, A., \& Govindarajan, V. (1984). Business unit strategy, managerial characterisitics, and business unit effectiveness at strategy implementation. Academy of Management Journal, 27, 25-41.

Gupta, A. K., \& Govindarajan, V. (1991). Knowledge flows and the structure of control within multinational corporations. Academy of Management Review, 16, 769-792.

Håkansson, H., \& Snehota, I. (1995). Developing relationships in networks. London: Routledge.

Hansen, M. (2002). Knowledge networks: Explaining effective knowledge sharing in multiunit companies. Organization Science, 13, 232- 248.

Hansen, M. T. (1999). The search-transfer problem: The role of weak ties in sharing knowledge across organization subunits. Administrative Science Quarterly, 44, 82111.

Hill, C. W. L., Hitt, M. A., \& Hoskisson, R. E. (1992). Cooperative versus competitive structures in related and unrelated diversified firms. Organization Science, 3, 501521.

Hoque, Z. (2005). Linking environmental uncertainty to non-financial performance measures and performance: A research note. The British Accounting Review, 37, 471-481.

Jarvis, C. B., Mackenzie, S. B., \& Podsakoff, P. M. (2003). A critical review of construct indicators and measurement model misspecification in marketing and consumer research. Journal of Consumer Research, 30, 199-218.

Jaussaud, J., \& Schaaper, J. (2006). Control mechanisms of their subsidiaries by multinational firms: a multidimensional perspective. Journal of International Management, 12, 23-45.

Kober, R., Ng, J., \& Paul, B. J. (2007). The interrelationship between management control mechanisms and strategy. Management Accounting Research, 18, 425-452.

Kostova, T., \& Zaheer, S. (1999). Organizational legitimacy under conditions of complexity: The case of the multinational enterprise. Academy of Management Review, 24, 64-81.

Kruis, A. (2008). Management control system design and effectiveness. $\mathrm{PhD}$ thesis (Nyenrode Business Universiteit.

Lane, P. J., \& Lubatkin, M. A. (1998). Relative absorptive capacity and interorganizational learning. Management Journal, 19, 461-477.

Langfield-Smith, K. (1997). Management control systems and strategy: A critical review. Accounting, Organizations and Society, 22, 207-232.

Luo, Y., \& Tang, R. L. (2007). International expansion of emerging countries enterprises: A springboard perspective. Journal of International Business Studies, 38, 481-498.

Malmi, T., \& Brown, D. A. (2008). Management control systems as a packageopportunities, challenges and research directions. Management Accounting Research, 19, 287-300.

Merchant, K. A., \& Van der Stede, W. A. (2012). Management control systems: Performance measurement, evaluation and incentives: Prentice Hall).

Miles, R. W., \& Snow, C. C. (1978). Organizational strategy, structure and process New York: McGraw Hill.

Muralidharan, R., \& Hamilton, R. D. (1999). Aligning multinational control systems. Long Range Planning, 32, 352-361.

Murray, A. I. (1988). A contingency view of Porter's "generic strategies". Academy of Management Review, 13, 390-400. 
Nilsson, F. (2002). Strategy and management control systems: A study of the design and use of management control systems following takeover. Accounting and Finance, 42, 4171.

O'Brien, R. M. (2007). A caution regarding the rules of thumb for variance inflation factors. Quality \& Quantity, 41, 673-690.

Park, C. (2002). The effects of prior performance on the choice between related and unrelated acquisitions: Implications for the performance consequences of diversification strategy. Journal of Management Studies, 37, 1003-1019.

Podsakoff, P. M., \& Organ, D. W. (1986). Self-reports in organizational research: Problems and prospects. Journal of management, 12, 531-544.

Porter, M. E. (1987). From competitive advantage to corporate strategy. Harvard Business Review, May-June.

Rumelt, R. P. (1974). Strategy, Structure and Economic Performance. Cambridge, Ma.: Harvard University Press.

Sandino, T. (2007). Introducing the first management control systems: evidence from the retail sector. The Accounting Review, 82, 265-293.

Schulz, M. (2001). The uncertain relevance of newness: Organizational learning and knowledge flows. Academy of Management Journal, 44, 661-681.

Shields, M. D. (2015). Established management accounting knowledge. Journal of Management Accounting Research, 27, 123-132.

Shroff, N., Verdi, R. S., \& Yu, G. (2014). Information environment and the investment decisions of multinational corporations. The Accounting Review, 89, 759-790.

Simons, R. (1994). Levers of control. Boston, Massachusetts: Harvard Business School Press.

Speklé, R. F. (2001). Explaining management control structure variety: a transaction cost economics perspective. Accounting, Organizations and Society, 26, 419-441.

Spicer, B., \& Ballew, V. (1983). Management accounting systems and the economics of internal organization. Accounting, Organizations and Society, 8, 73-96.

Talay, M. B., \& Cavusgil, S. T. (2008). Choice of ownership mode in joint ventures: An event history analysis from the automotive Industry. Industrial Marketing Management, 38, 71-82.

Tallman, S., \& Fladmoe-Lindquist, K. (2002). Internationalization, globalization, and capability-based strategy. Calfornia Management Review, 45, 116-135.

Thompson, J. (1967). Organizations in Action: McGraw Hill.

Tihanyi, L., \& Thomas, W. B. (2005). Information-processing demands and the multinational enterprise: A comparison of foreign and domestic earnings estimates. Journal of Business Research, 58, 285-292.

Tucker, B., Thorne, H., \& Gurd, B. (2009). Management Control Systems and Strategy: What's Been Happening? Journal of Accounting Literature, 28, 123-163.

Tucker, B. P., \& Lowe, A. D. (2014). Practitioners are from Mars; academics are from Venus?: An investigation of the research-practice gap in management accounting. Accounting, Auditing \& Accountability Journal, 27, 394-425.

Tucker, B. P., \& Parker, L. D. (2015). Business as usual? An institutional view of the relationship between management control systems and strategy. Financial Accountability \& Management, 31, 113-149.

Ungson, G., Braunstein, D., \& Hall, P. (1981). Managerial information processing: A research review. Administrative Science Quarteriy,, 26, 116-134.

Vachani, S. (2005). Problems of foreign subsidiaries of SMEs compared with large companies. International Business Review, 14, 415-439. 
White, G. O., Hemphill, T. A., Joplin, J. R. W., \& Marsh, L. A. (2014). Wholly owned foreign subsidiary relation-based strategies in volatile environments. International Business Review, 23, 303-312.

Williamson, O. E. (1975). Markets and hierarchies: New York: Free Press).

Williamson, O. E. (1979). Transaction-cost economics: The governance of contractual relations. The Journal of Law and Economics, 22, 234-235.

Williamson, O. E. (2005). Transaction cost economics and business administration. Scandinavian Journal of Management, 21, 19-40.

Williamson, O. E. (2008). Transaction cost economics: the precursors. Institute of Economic Affairs, September. 


\section{Tables}

Table 1 - Company positions of survey respondents

\begin{tabular}{lcc}
\hline Position & Frequency & Percentage \\
\hline Chief Executive Officer/Managing Director & 75 & 47.2 \\
General Manager & 17 & 10.7 \\
Financial Controller & 16 & 10.1 \\
Chief Financial Officer & 14 & 8.8 \\
Executive Director & 13 & 8.2 \\
Chairman & 6 & 3.8 \\
Company Secretary & 6 & 3.8 \\
Finance Manager & 5 & 3.1 \\
Chief Operating Officer & 3 & 1.9 \\
Group Accounting Manager & 2 & 1.3 \\
Other & 2 & 1.3 \\
Total & 159 & 100.0 \\
\hline
\end{tabular}


Table 2 - Respondent characteristics

Panel A - Industry classification of sample firms

\begin{tabular}{lcccc}
\hline Industry & \multicolumn{2}{c}{ Corporation } & \multicolumn{2}{c}{ Subsidiary } \\
\cline { 2 - 5 } & Frequency* & Percentage & Frequency* & Percentage \\
\hline Mining & 46 & 20.4 & 37 & 18.5 \\
Manufacturing & 38 & 16.8 & 27 & 13.5 \\
Other Services & 26 & 11.5 & 26 & 13.0 \\
Professional, Scientific \& Technical & & & & \\
Services & 18 & 8.0 & 19 & 9.5 \\
Information Media \& & & & & \\
Telecommunications & 16 & 7.1 & 15 & 7.5 \\
Finance \& Insurance Services & 13 & 5.8 & 12 & 6.0 \\
Wholesale Trade & 13 & 5.8 & 16 & 8.0 \\
Construction & 11 & 4.9 & 10 & 5.0 \\
Electricity, Gas, Water \& Waste Services & 8 & 3.5 & 8 & 4.0 \\
Retail Trade & 7 & 3.1 & 5 & 2.5 \\
Agriculture, Forestry \& Fishing & 6 & 2.7 & 5 & 2.5 \\
Health Care \& Social Assistance & 6 & 2.7 & 6 & 3.0 \\
Transport, Postal \& Warehousing & 6 & 2.7 & 4 & 2.0 \\
Administrative \& Support Services & 5 & 2.2 & 4 & 2.0 \\
Rental, Hiring \& Real Estate Services & 3 & 1.3 & 4 & 2.0 \\
Accommodation \& Food Services & 1 & 0.4 & 0 & 0.0 \\
Arts \& Recreation Services & 1 & 0.4 & 1 & 0.5 \\
Education \& Training & 1 & 0.4 & 1 & 0.5 \\
Public Administration \& Safety & 1 & 0.4 & 0 & 0.0 \\
\hline *Total frequency higher than sample size (159) due to some firms indicating involvement in multiple \\
industries. & & & &
\end{tabular}

\section{Panel B - Subsidiary location}

\begin{tabular}{lcc}
\hline \multicolumn{1}{c}{ Region } & Frequency & Percentage \\
\hline North America & 42 & 26.4 \\
Asia & 34 & 21.4 \\
Oceania & 34 & 21.4 \\
Europe & 27 & 17.0 \\
Africa & 16 & 10.1 \\
Middle East & 4 & 2.5 \\
South America & 2 & 1.3 \\
\hline
\end{tabular}


Table 3 - Descriptive statistics ${ }^{\wedge}$

\begin{tabular}{llcrrr}
\hline & Min. & Max. & Mean & Median & Std. Dev. \\
\hline Arm's length control & 1.000 & 5.000 & 2.962 & 3.000 & 0.992 \\
Results control & 2.097 & 5.000 & 4.150 & 4.181 & 0.560 \\
Action control & 1.500 & 5.000 & 3.560 & 3.667 & 0.785 \\
Boundary control & 2.000 & 5.000 & 3.829 & 3.833 & 0.709 \\
Exploratory control & 2.250 & 5.000 & 4.129 & 4.000 & 0.485 \\
Degree of control & 2.267 & 4.900 & 3.733 & 3.767 & 0.519 \\
Corporate strategy & 1.000 & 4.667 & 1.732 & 1.667 & 0.797 \\
Low cost competitive strategy & 2.000 & 5.000 & 3.782 & 4.000 & 0.753 \\
Differentiation competitive strategy & 1.000 & 5.000 & 3.369 & 3.400 & 0.844 \\
Corporate embeddedness & 1.000 & 5.000 & 3.195 & 3.000 & 0.997 \\
External embeddedness & 1.000 & 5.000 & 3.082 & 3.000 & 0.742 \\
Size (employees) & 5.000 & $38,000.000$ & 1989.138 & 180.000 & 5848.405 \\
\hline ^ The statistics reported in this table are based on the non-normalised variables. Where appropriate the variables \\
are normalised, consistent with the assumptions of OLS regression. & \multicolumn{3}{c}{}
\end{tabular}


Table 4 - Regression results

\begin{tabular}{|c|c|c|c|c|c|c|c|c|c|c|c|c|c|}
\hline \multirow[t]{2}{*}{ Control } & \multirow{2}{*}{$\begin{array}{c}\text { Predicted } \\
\text { sign }\end{array}$} & \multicolumn{2}{|c|}{ Degree of control } & \multicolumn{2}{|c|}{ Arm's length } & \multicolumn{2}{|c|}{ Results } & \multicolumn{2}{|c|}{ Action } & \multicolumn{2}{|c|}{ Boundary } & \multicolumn{2}{|c|}{ Exploratory } \\
\hline & & Coeff. & $t$-stat & Coeff. & $t$-stat & Coeff. & $t$-stat & Coeff. & $t$-stat & Coeff. & $t$-stat & Coeff. & $t$-stat \\
\hline Corporate strategy & - & $-0.216^{* * *}$ & -3.030 & -0.071 & -0.937 & $-0.222 * * *$ & -3.045 & $-0.147^{*}$ & -1.934 & $-0.164 * *$ & -2.134 & $-0.270 * * *$ & -3.411 \\
\hline Low cost competitive strategy & + & $0.268 * * *$ & 3.727 & $0.158 * *$ & 2.083 & 0.096 & 1.308 & $0.249 * * *$ & 3.243 & $0.277 * * *$ & 3.573 & $0.150^{*}$ & 1.875 \\
\hline Differentiation competitive strategy & - & $0.138^{*}$ & 1.918 & $0.284 * * *$ & 3.737 & 0.082 & 1.118 & -0.003 & -0.035 & 0.031 & 0.398 & 0.065 & 0.812 \\
\hline Corporate embeddedness & + & $0.191 * *$ & 2.627 & 0.089 & 1.160 & $0.217 * * *$ & 2.911 & $0.171^{* *}$ & 2.199 & $0.205^{* * *}$ & 2.620 & 0.014 & 0.170 \\
\hline External embeddedness & - & $0.122 *$ & 1.670 & $0.134 *$ & 1.725 & 0.122 & 1.617 & $0.135^{*}$ & 1.719 & -0.019 & -0.242 & 0.044 & 0.536 \\
\hline Size & & $0.193 * * *$ & 2.690 & 0.082 & 1.087 & $0.323 * * *$ & 4.399 & $0.164 * *$ & 2.139 & 0.122 & 1.578 & 0.088 & 1.106 \\
\hline Adjusted R square & & \multicolumn{2}{|c|}{0.260} & \multicolumn{2}{|c|}{0.172} & \multicolumn{2}{|c|}{0.222} & \multicolumn{2}{|c|}{0.155} & \multicolumn{2}{|c|}{0.138} & \multicolumn{2}{|c|}{0.084} \\
\hline F-stat (significance) & & \multicolumn{2}{|c|}{$10.246 * * *(0.000)$} & \multicolumn{2}{|c|}{$6.452 * * *(0.000)$} & \multicolumn{2}{|c|}{$8.515 * * *(0.000)$} & \multicolumn{2}{|c|}{$5.825 * * *(0.000)$} & \multicolumn{2}{|c|}{$5.198 * * *(0.000)$} & \multicolumn{2}{|c|}{$3.416 * * *(0.003)$} \\
\hline
\end{tabular}


Table 5 - Multinominal logistic regression

Panel A - Control archetype choice relative to arm's length control

\begin{tabular}{|c|c|c|c|c|c|c|c|c|}
\hline \multirow[t]{2}{*}{ Independent variable } & \multicolumn{2}{|c|}{ Results control } & \multicolumn{2}{|c|}{ Action control } & \multicolumn{2}{|c|}{ Boundary control } & \multicolumn{2}{|c|}{ Exploratory control } \\
\hline & Coefficient & Wald & Coefficient & Wald & Coefficient & Wald & Coefficient & Wald \\
\hline Corporate strategy & 0.065 & 0.009 & -0.039 & 0.002 & -0.496 & 0.441 & -0.617 & 0.743 \\
\hline Low cost competitive strategy & $-2.519 * *$ & 5.849 & $-2.553 * *$ & 4.291 & $-1.916^{*}$ & 3.262 & $-2.565 * *$ & 6.057 \\
\hline Differentiation competitive strategy & -0.960 & 1.853 & -0.685 & 0.600 & -0.765 & 1.087 & -1.032 & 2.148 \\
\hline Corporate embeddedness & 0.303 & 0.327 & -0.547 & 0.541 & 0.622 & 1.230 & 0.380 & 0.508 \\
\hline External embeddedness & -0.303 & 0.134 & 1.364 & 1.266 & -1.066 & 1.550 & -0.742 & 0.806 \\
\hline Size & 0.000 & 0.674 & 0.000 & 0.074 & 0.000 & 0.770 & 0.000 & 0.307 \\
\hline Intercept & $15.878 * * *$ & 6.164 & 10.322 & 1.918 & $14.132 * *$ & 4.697 & $18.492 * * *$ & 8.316 \\
\hline
\end{tabular}

$\%$ Correctly classified

Arm's length control: 4.4\%; Results control: 40.7\%; Action control: 4.4\%;

Boundary control: $14.8 \%$; Exploratory control: $35.6 \%$

Model chi-square $41.969 * *$ ( 24 d.f.)

***Significant at the 0.01 level; **Significant at the 0.05 level; *Significant at the 0.10 level (two tailed)

Panel B - Control archetype choice relative to results control

Independent variable $\quad$ Arm's length control

Coefficient Wald

$-0.065 \quad 0.009$

$2.519 * * \quad 5.849$

$0.960 \quad 1.853$

$-0.303 \quad 0.327$

$0.303 \quad 0.134$

$0.000 \quad 0.674$

$-15.878 * *$

6.164

Action control

Boundary control

$\begin{array}{ccccc}\text { Coefficient } & \text { Wald } & & \text { Coefficient } & \text { Wald } \\ -0.104 & 0.027 & & -0.561 & 2.295\end{array}$

ald

$-0.034 \quad 0.002$

0.603

2.482

$\begin{array}{llll}0.275 & 0.199 & 0.194 & 0.290\end{array}$

$-0.850 * 2.193$

$0.319 \quad 1.178$

$1.668 * 3.109$

$-0.762 *$

3.556

$0.000 \quad 0.773$

$0.000 \quad 0.171$

$-5.556 \quad 1.770$

$-1.746$

0.607

\begin{tabular}{cc}
\multicolumn{2}{c}{ Exploratory control } \\
\hline Coefficient & Wald \\
\hline$-0.682^{* *}$ & 5.615 \\
-0.046 & 0.025 \\
-0.072 & 0.073 \\
0.077 & 0.120 \\
-0.439 & 1.932 \\
0.000 & 1.032 \\
2.614 & 2.571
\end{tabular}

$\%$ Correctly classified

Arm's length control: 4.4\%; Results control: 40.7\%; Action control: 4.4\%;

Boundary control: $14.8 \%$; Exploratory control: $35.6 \%$

Model chi-square $41.969 * *$ ( 24 d.f.)

***Significant at the 0.01 level; **Significant at the 0.05 level; *Significant at the 0.10 level (two tailed) 
Panel C - Control archetype choice relative to action control

\begin{tabular}{|c|c|c|c|c|c|c|c|c|}
\hline \multirow[t]{2}{*}{ Independent variable } & \multicolumn{2}{|c|}{ Arm's length control } & \multicolumn{2}{|c|}{ Results control } & \multicolumn{2}{|c|}{ Boundary control } & \multicolumn{2}{|c|}{ Exploratory control } \\
\hline & Coefficient & Wald & Coefficient & Wald & Coefficient & Wald & Coefficient & Wald \\
\hline Corporate strategy & 0.039 & 0.002 & 0.104 & 0.027 & -0.457 & 0.421 & -0.579 & 0.768 \\
\hline Low cost competitive strategy & $2.553 * *$ & 4.291 & 0.034 & 0.002 & 0.636 & 0.653 & -0.012 & 0.000 \\
\hline Differentiation competitive strategy & 0.685 & 0.600 & -0.275 & 0.199 & -0.081 & 0.014 & -0.347 & 0.314 \\
\hline Corporate embeddedness & 0.547 & 0.541 & 0.850 & 2.193 & $1.169^{*}$ & 3.638 & 0.927 & 2.578 \\
\hline External embeddedness & -1.364 & 1.266 & $-1.668 *$ & 3.109 & $-2.430 * *$ & 6.030 & $-2.106 * *$ & 4.899 \\
\hline Size & 0.000 & 0.074 & 0.000 & 0.773 & 0.000 & 0.842 & 0.000 & 0.489 \\
\hline Intercept & -10.322 & 1.918 & 5.556 & 1.770 & 3.810 & 0.711 & $8.170 *$ & 3.751 \\
\hline
\end{tabular}

Intercept

$3.810 \quad 0.711$

$8.170^{*} \quad 3.751$

$\%$ Correctly classified

Arm's length control: 4.4\%; Results control: 40.7\%; Action control: 4.4\%;

Boundary control: $14.8 \%$; Exploratory control: $35.6 \%$

Model chi-square

$41.969 * *$ ( 24 d.f.)

***Significant at the 0.01 level; **Significant at the 0.05 level; *Significant at the 0.10 level (two tailed)

Panel D - Control archetype choice relative to boundary control

\begin{tabular}{|c|c|c|c|c|c|c|c|c|}
\hline \multirow[t]{2}{*}{ Independent variable } & \multicolumn{2}{|c|}{ Arm's length control } & \multicolumn{2}{|c|}{ Results control } & \multicolumn{2}{|c|}{ Action control } & \multicolumn{2}{|c|}{ Exploratory control } \\
\hline & Coefficient & Wald & Coefficient & Wald & Coefficient & Wald & Coefficient & Wald \\
\hline Corporate strategy & 0.496 & 0.441 & 0.561 & 2.295 & 0.457 & 0.421 & -0.121 & 0.092 \\
\hline Low cost competitive strategy & $1.916^{*}$ & 3.262 & -0.603 & 2.482 & -0.636 & 0.653 & $-0.649 *$ & 2.906 \\
\hline Differentiation competitive strategy & 0.765 & 1.087 & -0.194 & 0.290 & 0.081 & 0.014 & -0.266 & 0.559 \\
\hline Corporate embeddedness & -0.622 & 1.230 & -0.319 & 1.178 & $-1.169 *$ & 3.638 & -0.242 & 0.680 \\
\hline External embeddedness & 1.066 & 1.550 & $0.762 *$ & 3.556 & $2.430 * *$ & 6.030 & 0.323 & 0.699 \\
\hline Size & 0.000 & 0.770 & 0.000 & 0.171 & 0.000 & 0.842 & 0.000 & 1.390 \\
\hline & & & & & & & & \\
\hline
\end{tabular}

Intercept

$\%$ Correctly classified

Model chi-square

*** Significant at the 0.01 level;
Arm's length control: 4.4\%; Results control: 40.7\%; Action control: 4.4\%;

Boundary control: $14.8 \%$; Exploratory control: $35.6 \%$

$41.969 * *$ ( 24 d.f. $)$ 